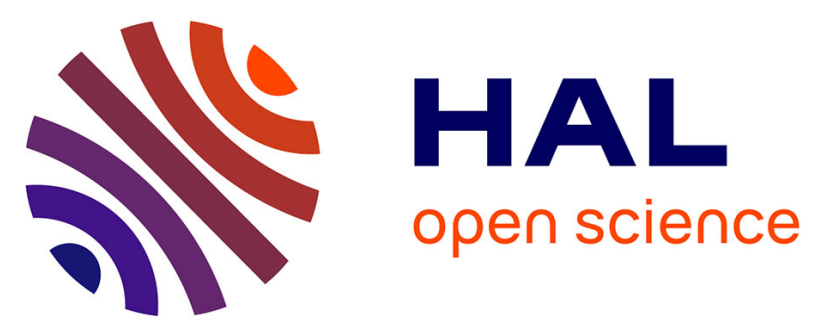

\title{
Influence of Processing Additives on the Quality and Stability of Dried Papaya Obtained by Osmotic Dehydration and Conventional Air Drying
}

Sílvia P M Germer, Cristhiane C Ferrari, Julia P Lancha, Shirley a G Berbari, Sandra M Carmello-Guerreiro, Cristiane R G Ruffi

\section{To cite this version:}

Sílvia P M Germer, Cristhiane C Ferrari, Julia P Lancha, Shirley a G Berbari, Sandra M CarmelloGuerreiro, et al.. Influence of Processing Additives on the Quality and Stability of Dried Papaya Obtained by Osmotic Dehydration and Conventional Air Drying. Drying Technology, 2014, 32 (16), pp.1956-1969. 10.1080/07373937.2014.924963 . hal-03426117

\section{HAL Id: hal-03426117 https://hal.science/hal-03426117}

Submitted on 12 Nov 2021

HAL is a multi-disciplinary open access archive for the deposit and dissemination of scientific research documents, whether they are published or not. The documents may come from teaching and research institutions in France or abroad, or from public or private research centers.
L'archive ouverte pluridisciplinaire HAL, est destinée au dépôt et à la diffusion de documents scientifiques de niveau recherche, publiés ou non, émanant des établissements d'enseignement et de recherche français ou étrangers, des laboratoires publics ou privés. 
See discussions, stats, and author profiles for this publication at: https://www.researchgate.net/publication/264978555

\section{Influence of Processing Additives on The Quality and Stability of Dried Papaya Obtained by Osmotic Dehydration and Conventional Air Drying}

Article in Drying Technology · December 2014

DOI: 10.1080/07373937.2014.924963

CITATIONS

15

6 authors, including:

Silvia Pimentel Marconi Germer

Instituto de Tecnologia de Alimentos

37 PUBLICATIONS 791 CITATIONS

SEE PROFILE

$\sqrt{-10}$

Julia Parlatore Lancha

CentraleSupélec

7 PUBliCATIONS 32 CITATIONS

SEE PROFILE
READS

355

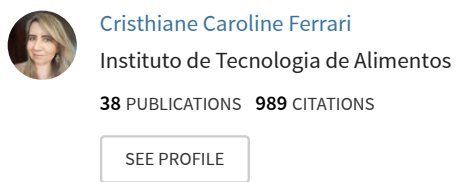

बिक्षे

Sandra Carmello Guerreiro

University of Campinas

76 PUBLICATIONS 1,023 CITATIONS

SEE PROFILE

Some of the authors of this publication are also working on these related projects:

Drying Technology View project

"Molecular and morphoanatomical phylogeny of the genus Acrocomia (Arecaceae): a taxonomic study of a group of native palm trees with great socioeconomic and environmental interest" View project 
This article was downloaded by: [Sílvia P. M. Germer]

On: 12 June 2014, At: 08:00

Publisher: Taylor \& Francis

Informa Ltd Registered in England and Wales Registered Number: 1072954 Registered office: Mortimer House, 37-41 Mortimer Street, London W1T 3J H, UK

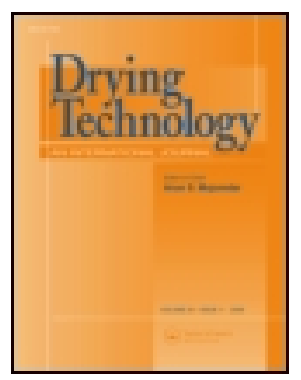

\title{
Drying Technology: An International J ournal
}

Publication details, including instructions for authors and subscription information:

http:// www.tandfonline.com/loi/ldrt20

\section{Influence of Processing Additives on the Quality and Stability of Dried Papaya Obtained by Osmotic Dehydration and Conventional Air Drying}

\author{
Sílvia P. M. Germer ${ }^{a}$, Cristhiane C. Ferrari ${ }^{a}$, Julia P. Lancha ${ }^{c}$, Shirley A. G. Berbari ${ }^{a}$, \\ Sandra M. Carmello-Guerreiro ${ }^{d} \&$ Cristiane R. G. Ruffi ${ }^{b}$ \\ ${ }^{a}$ Fruit and Vegetable Technology Center, Institute of Food Technology, ITAL, Campinas, SP , \\ Brazil \\ ${ }^{\mathrm{b}}$ Cereal and Chocolate Technology Center, Institute of Food Technology, ITAL, Brazil \\ ${ }^{c}$ Food Engineering College, State University of Campinas, Unicamp, Campinas, Brazil \\ d Department of Botany, Institute of Biology, State University of Campinas, Unicamp , \\ Campinas, Brazil \\ Accepted author version posted online: $11 \mathrm{~J}$ un 2014. Published online: $11 \mathrm{~J}$ un 2014.
}

To cite this article: Sílvia P. M. Germer , Cristhiane C. Ferrari , J ulia P. Lancha, Shirley A. G. Berbari, Sandra M.

Carmello-Guerreiro \& Cristiane R. G. Ruffi (2014): Influence of Processing Additives on the Quality and Stability of Dried Papaya Obtained by Osmotic Dehydration and Conventional Air Drying, Drying Technology: An International J ournal, DOI: $10.1080 / 07373937.2014 .924963$

To link to this article: http:// dx.doi.org/ 10.1080/07373937.2014.924963

Disclaimer: This is a version of an unedited manuscript that has been accepted for publication. As a service to authors and researchers we are providing this version of the accepted manuscript (AM). Copyediting, typesetting, and review of the resulting proof will be undertaken on this manuscript before final publication of the Version of Record (VoR). During production and pre-press, errors may be discovered which could affect the content, and all legal disclaimers that apply to the journal relate to this version also.

\section{PLEASE SCROLL DOWN FOR ARTICLE}

Taylor \& Francis makes every effort to ensure the accuracy of all the information (the "Content") contained in the publications on our platform. However, Taylor \& Francis, our agents, and our licensors make no representations or warranties whatsoever as to the accuracy, completeness, or suitability for any purpose of the Content. Any opinions and views expressed in this publication are the opinions and views of the authors, and are not the views of or endorsed by Taylor \& Francis. The accuracy of the Content should not be relied upon and should be independently verified with primary sources of information. Taylor and Francis shall not be liable for any losses, actions, claims, proceedings, demands, costs, expenses, damages, and other liabilities whatsoever or howsoever caused arising directly or indirectly in connection with, in relation to or arising out of the use of the Content.

This article may be used for research, teaching, and private study purposes. Any substantial or systematic reproduction, redistribution, reselling, loan, sub-licensing, systematic supply, or distribution in any 
form to anyone is expressly forbidden. Terms \& Conditions of access and use can be found at http:// www.tandfonline.com/page/terms-and-conditions 


\title{
ACCEPTED MANUSCRIPT
}

\section{Influence of Processing Additives on The Quality and Stability of Dried Papaya Obtained by Osmotic Dehydration and Conventional Air Drying}

\author{
Sílvia P. M. Germer ${ }^{1}$, Cristhiane C. Ferrari ${ }^{1}$, Julia P. Lancha ${ }^{3}$, Shirley A. G. Berbari ${ }^{1}$,
} Sandra M. Carmello-Guerreiro ${ }^{4}$, Cristiane R. G. Ruffi ${ }^{2}$

${ }^{1}$ Fruit and Vegetable Technology Center, Institute of Food Technology, ITAL, Campinas, SP, Brazil ${ }^{2}$ Cereal and Chocolate Technology Center, Institute of Food Technology, ITAL, Brazil ${ }^{3}$ Food Engineering College, State University of Campinas, Unicamp, Campinas, Brazil ${ }^{4}$ Department of Botany, Institute of Biology, State University of Campinas, Unicamp, Campinas, Brazil

Corresponding author: S. P. M. Germer Fruit and Vegetable Technology Center, Institute of Food Technology, ITAL, Av. Brasil, 2880, 13070-178 Campinas, SP, Brazil E-mail: sgermer@ital.sp.gov.br

The combination of osmotic dehydration and hot air drying (OD/HA) is an industrial alternative to Papaya production, but tissue softening and color loss are technological problems. The objective of this work was to study, during OD/HA processing of papaya (Formosa cultivar), the influence of organic acids (citric and lactic), calcium salts (lactate and chloride), and the enzyme pectinmethylesterase (PME) on the texture, color and sensory characteristics of the product. The stability of the products treated with lactic acid/calcium chloride, PME/calcium chloride and the standard sample (without additives) was evaluated at $25^{\circ} \mathrm{C}$ and $35^{\circ} \mathrm{C}$ for up to 100 days, analyzing vitamin $\mathrm{C}$ and color degradation. Light microscopy analysis performed at the beginning of stability study showed that the additives better preserved the cell structure. The use of lactic acid/calcium chloride maintained the color of the dried papaya, but the additives did not have an effect on vitamin $\mathrm{C}$ degradation. The variations in the chromaticity parameters $\left(b^{*}\right.$ and $\left.a^{*}\right)$ were adjusted to zero and first order kinetic models, respectively, with $\mathrm{Q}_{10}$

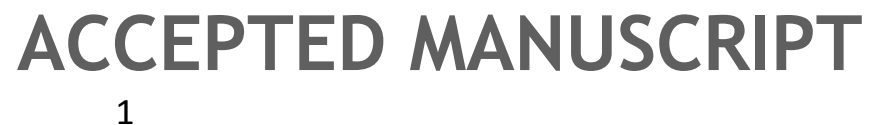




\section{ACCEPTED MANUSCRIPT}

values ranging between 0.88 and 2.30 and $\mathrm{R}^{2} \sim 0.90$. The combination of lactic

acid/calcium chloride resulted in higher sensory acceptance and color stability of dried papaya during storage.

KEYWORDS: calcium, pectinmethylesterase, color, vitamin C, kinetics

\section{INTRODUCTION}

Brazil is the greatest world producer of Papaya (Carica papaya L.) with 1.8 million tons per year, and the second largest exporter of the fresh fruit. ${ }^{[1,2]}$ Three different cultivars are grown: Comum, Solo and Formosa. The production of Formosa cultivar is directed to the internal market, resulting in larger fruits with greater transportation resistance and containing higher sugar contents. ${ }^{[3]}$ The fruit has a high nutritive value, being rich in vitamin C (30-130 mg/100 g), vitamin B1 (40-45 mg/100 g), B2 (40-50 mg/100 g) and A (1200-1650 units/100 g), as well as minerals such as potassium $(222 \mathrm{mg} / 100 \mathrm{~g})$ and magnesium (17 mg/100 g). ${ }^{[3,4]}$ Papaya, principally the red pulp ones such as Formosa cultivar, is also an important source of lycopene ( 21 to $29.6 \mu \mathrm{g} / \mathrm{g}$ ), a bioactive compound with preventative action against heart diseases and some types of cancer. ${ }^{[5,6]}$

The production of dried fruits could be an alternative to exploit any excess fruit production, offering the opportunity to add value to the product and generate jobs and income. On the other hand, dried fruit products present some aspects, such as healthiness and convenience, attending new tendencies for food consumption. ${ }^{[7]}$ 


\section{ACCEPTED MANUSCRIPT}

The production of dried fruit using the combined method of osmotic dehydration (OD) and complementary hot air drying (HA) is a technological alternative with some advantages when compared with conventional processes, improving nutritional and sensory properties of air-dried products. ${ }^{[8]} \mathrm{OD}$ has been studied as a preliminary step in the drying of fruits, and consists of immersing them in a hypertonic solution of one or more solutes, such that the partial removal of water occurs mainly due to the chemical potential established. ${ }^{[9,10]}$ The combination of both techniques has been employed in several fruits, such as cherry tomato ${ }^{[11]}$, mulberry ${ }^{[12]}$, seabuckthorn fruits ${ }^{[13]}$, strawberry ${ }^{[14]}$ and chayote ${ }^{[15]}$, resulting in products with good quality.

Some studies have reported the potential for the application of osmotic dehydration (OD) in papaya processing. ${ }^{[3,9,16-19]}$ However, the technique presents some technological problems which complicate the industrial scale process, notably softening of the vegetable tissue during OD and loss of color. ${ }^{[17]}$ The cell tissues of papaya are highly fragile, tending to collapse during the process as a function of the ripening stage and time-temperature conditions, making them difficult to handle, which results in losses. In addition, due to carotenoid oxidation, the color of the fruit undergoes changes during shelf life, compromising product quality. ${ }^{[9,16]}$

The application of organic acids and calcium salts during OD of papaya has been reported in the literature with the aim of minimizing these problems. Weak acids such as lactic and citric acids prevent the color change due to the inhibition of enzymatic browning, while the calcium salts (calcium lactate and chloride) are applied as texture 


\section{ACCEPTED MANUSCRIPT}

agents ${ }^{[16-18,20-22]}$. According to Suttirak \& Manurakchinakorn ${ }^{[23]}$ weak acids retard browning by lowering the $\mathrm{pH}$ of the product, minimizing the activity of poliphenol oxydase (PPO). Some acids like citric acid also delay discoloration by chelating the copper at PPO active site. According to Chiumarelli et al. ${ }^{[20]}$, the use of weak acids, such as citric acid, can avoid enzymatic browning of plant tissue, thereby reducing the product appearance loss. The calcium ion is supposed to form a complex with pectin in the cell wall and middle lamella of vegetable tissue, resulting in a firmer structure. ${ }^{[17]}$

The use of the enzyme pectinmethylesterase (PME) associated with calcium salts has also been evaluated as a texture agent in fruit processing. PME is produced by fungi and catalyzes the hydrolysis of methyl esters on the pectin molecule, resulting in pectin free of carboxyl groups, whose negative charges bind to $\mathrm{Ca}^{2+}$ ions forming a tridimensional matrix and promoting greater resistance of the cell wall middle lamella. The use of PME associated to calcium chloride was reported in the combined $\mathrm{OD} /$ freezing and heat processing/high pressure processes of strawberries. ${ }^{[24,25]}$ However, the application of PME/calcium chloride in the combined osmotic dehydration/hot air drying process has not been reported yet.

In this context, the objective of the present study was to analyze the effect of some organic acids (citric and lactic) associated with calcium salts (lactate and chloride) on the combined OD/HA processing of papaya. The use of PME with calcium chloride was also evaluated as an alternative, since its application is completely unknown. Technological

\section{ACCEPTED MANUSCRIPT




\title{
ACCEPTED MANUSCRIPT
}

aspects such as texture, color and stability of the final products during storage were determined.

\section{MATERIAL AND METHODS}

\section{Raw Material}

Papayas of Formosa cultivar $(\sim 2.5 \mathrm{~kg})$ were obtained from the local market in Campinas, Brazil, and stored at room temperature for maturation. The fruits were used in the maturity state denominated as $3 / 4$, when 50 to $75 \%$ of the skin is yellow. ${ }^{[26]}$ Table 1 shows the physicochemical characteristics of the raw material.

\begin{abstract}
Refined sugar of the brand União (Coopersucar, Piracicaba, Brazil) was used to prepare the osmotic solution. The acids and organic salts were obtained from Labsynth (Brazil). The enzyme E.C 3.1.1.11 (10 Pectin Esterase Units/ml) (NovoShape ${ }^{\mathrm{TM}}$, Novozyme, Denmark), obtained from a fermentation process with Aspergillus aculeatus, was used.
\end{abstract}

\section{Methodology}

The study was carried out in two steps: (1) Study of the effect of the additives on the combined OD/HA process; (2) Study of the stability during storage.

\section{Study Of The Effect Of The Additives On The Combined OD/HA Process Experimental OD/HA Trials}

The fruits were selected, washed with tap water, peeled and cut into slices of approximately $6 \times 2 \times 0.5 \mathrm{~cm}$. 


\section{ACCEPTED MANUSCRIPT}

According to some preliminary tests, the trials were carried out with the following combinations of additives: $0.1 \mathrm{M}$ citric acid with calcium lactate $(0.5 \mathrm{~g} / 100 \mathrm{~g}$ syrup$)$ (CA/CL); 0.1M lactic acid with calcium lactate ( $0.5 \mathrm{~g} / 100 \mathrm{~g}$ syrup) (LA/CL); $0.1 \mathrm{M}$ citric acid with calcium chloride $(0.5 \mathrm{~g} / 100 \mathrm{~g}$ syrup) $(\mathrm{CA} / \mathrm{CC}) ; 0.1 \mathrm{M}$ lactic acid with calcium chloride ( $0.5 \mathrm{~g} / 100 \mathrm{~g}$ syrup) (LA/CC); and PME ( $1 \mathrm{ml} / \mathrm{kg}$ fruit) with calcium chloride (1 $\mathrm{g} / \mathrm{kg}$ fruit) (PME/CC). The last trial, considered as the standard, was carried out without additives $(\mathrm{P})$.

The OD was carried out in an 8 liter heat controlled bath with circulation $(10 \mathrm{~L} / \mathrm{min})$ (Model 1266-02, Cole-Parmer, Vernon Hills, USA). The concentration of the sucrose syrup was $65^{\circ}$ Brix and the mass ratio of syrup to fruit was $4: 1$ (mass syrup: mass fruit). The additives were added to the syrup at the beginning of each trial. The manufacturer's instructions were followed in the trial with PME, using $1 \mathrm{ml}$ of enzyme (10 Pectin Esterase Units/ml) per $\mathrm{kg}$ of fruit, corresponding to $0.03 \mathrm{~g} / 100 \mathrm{~g}$ of syrup, plus $1 \mathrm{~g}$ calcium chloride per $\mathrm{kg}$ of fruit, corresponding to $0.03 \mathrm{~g} / 100 \mathrm{~g}$ of syrup. The process was performed for 2 hours at $50^{\circ} \mathrm{C}$, according to some preliminary tests. At the end of the $\mathrm{OD}$, the slices were removed from the bath, drained, rinsed with water and carefully drained with absorbent paper. The mass of the fruit was weighed at the beginning and at the end of OD using a mechanical balance (BPS-15, Filizola, São Paulo, Brazil), separating samples for the analyses.

\section{ACCEPTED MANUSCRIPT




\section{ACCEPTED MANUSCRIPT}

The osmo-dehydrated fruits were dried in a tray drier (K13964, Proctor \& Schwartz, Lexington, USA) with air circulation (velocity of $1.5 \mathrm{~m} / \mathrm{s}$ ) at $60^{\circ} \mathrm{C}$, for a time sufficient to obtain a final moisture content around $16 \%$.

\section{Mass Transfer Parameters}

During the osmotic dehydration process, water loss (WL) and solids incorporation (SI) were calculated using the following equations:

$$
\begin{aligned}
& W L=(U i M i-U f M f) / M i \times 100 \quad(\mathrm{~g} \text { of water } / 100 \mathrm{~g} \text { of initial mass }) \\
& S I=(S T f M f-S T i M i) / M i \times 100 \quad(\mathrm{~g} \text { of solute } / 100 \mathrm{~g} \text { of initial mass })
\end{aligned}
$$

\section{Analyses}

The raw material used in the trials was subjected to the following analyses: moisture content, vitamin $\mathrm{C}$ content and instrumental color. After OD, the osmo-dehydrated fruits were analyzed with respect to moisture content and vitamin $\mathrm{C}$ content. The final product after HA (dried fruits) was analyzed in terms of moisture content, water activity, color and texture. These samples were also subjected to a sensory analysis.

The moisture content was determined in a vacuum oven at $70^{\circ} \mathrm{C}$ to constant weight, according to $\mathrm{AOAC}^{[27]}$, and the water activity using a hygrometer (Aqualab-3TE, Decagon Devices Inc., Pullman, USA) at $25^{\circ} \mathrm{C}$. A colorimeter (CR400, Minolta, Osaka, Japan) was used for the color analyses making a direct reading of the sample with the $\mathrm{d} / 0$ configuration and D65 illuminant and employing the CIELAB system: chromaticity parameters $a^{*}$ (green [-] to red [+]) and $b^{*}$ (blue [-] to yellow [+]). Lightness $L^{*}\left(L^{*}=0\right.$

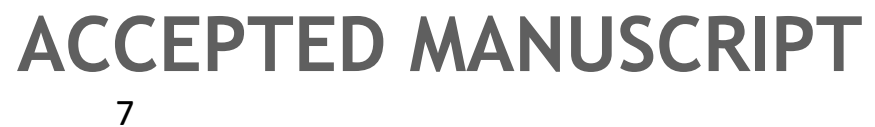




\section{ACCEPTED MANUSCRIPT}

for black and $L^{*}=100$ for white) was also measured. The texture (cutting force) was evaluated using a Universal Testing Machine (TA.XT2i Texture Analyzer, Stable Micro Systems, Godalming, England), with a blade set probe (HDP/BSK) and the HDP/90 platform. The parameters used in the test were: (i) pre-test velocity $=2.0 \mathrm{~mm} / \mathrm{s}$; (ii) test velocity $=1.0 \mathrm{~mm} / \mathrm{s}$; (iii) post-test velocity $=10.0 \mathrm{~mm} / \mathrm{s}$; (iv) distance $99 \%$ of the sample, with a compression force of 100 gram-force (gf), time of $5 \mathrm{~s}$, trigger of $5 \mathrm{~g}$ and load cell of $50 \mathrm{Kg}$. The vitamin $\mathrm{C}$ content was determined according to the titration method of Oliveira et al. ${ }^{[28]}$, and the percent retention of vitamin $\mathrm{C}$ in relation to the raw material calculated according to Murphy et al. ${ }^{\text {[29] }}$

The physicochemical analyses were carried out in triplicate. Fifteen samples were used per treatment for the texture determination (cutting force). Color analysis was performed with ten measurements taken from five samples per treatment. The results for these analyses are presented as the mean value plus the standard deviation. The means were statistically evaluated by the analysis of variance (ANOVA) using the Statistica 7.0 program (StatSoft, Inc., Tulsa, USA), and the separation of the means was determined employing Tukey's test at $\mathrm{p} \leq 0.05$.

\section{Sensory Analysis}

A sensory evaluation of the final products obtained from the trials with additives was carried out with a panel of 16 trained judges using horizontal structured scales with 4 adjectives for each attribute and 12 corresponding numerical points: appearance [bad (13)/ regular (4-6)/ good (7-9)/ optimum (10-12)]; orange color [weak (1-3)/ regular (4-6)/ 


\section{ACCEPTED MANUSCRIPT}

moderate (7-9)/ intense (10-12)]; texture/elasticity [low (1-3)/ regular (4-6)/ medium (7-

9)/ much (10-12)]; flavor [bad (1-3)/ regular (4-6)/ good (7-9)/ optimum (10-12)] and

overall quality (bad (1-3)/ regular (4-6)/ good (7-9)/ optimum (10-12)]. ${ }^{[30]}$ Standard treatments (without additives) were not subjected to sensory analysis, since the main goal of this work was to compare the treatments with the additives. Therefore, the use of standard samples in sensory tests could have interfered with the results, confusing the judges. The results were analyzed by the analysis of variance, F test and Tukey's test, employing the SAS program (Statistical Analysis System, SAS Institute Inc, USA).

\section{Stability Study Of The Dried Papaya Slices During Storage}

This study was carried out with the products obtained from two treatments chosen in the first step and also with the product treated without additives (standard). To obtain the samples, three new experimental OD/HA trials were carried out, under the same conditions described before. The products were packed into double film packages of low density polyethylene (LDPE) (1.5 mm thickness) and aluminum foil, and stored in a BOD incubator (LS370, Logen Scientific, Diadema, Brazil) at 25 or $35^{\circ} \mathrm{C}$ and relative humidity of $65 \%$ for 70 to 100 days.

At the beginning of the study, the dried fruits were subjected to light microscopy analysis and also to instrumental color, vitamin $\mathrm{C}$ content and moisture content analyses. The vitamin $\mathrm{C}$ and instrumental color were periodically evaluated during storage according to the methods previously described. Due to the low water activity values of the final products and some previous results, microbiological stability and $\mathrm{pH}$ analysis were not

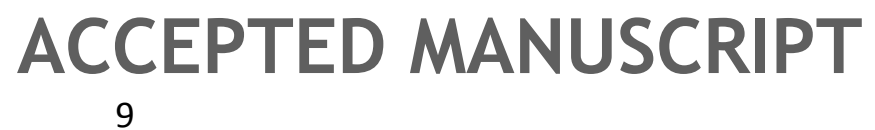




\section{ACCEPTED MANUSCRIPT}

performed. Water activity and moisture content were also not evaluated, due to the very good vapor barrier properties of the package employed. However, for a complete shelf life study these analyses should be considered.

\section{Light Microscopy}

Samples of fresh papaya and dried fruit were submitted to a cell structure analysis by light microscopy at zero time of the stability study. The samples were prepared according to the methodology described by Ferrari et al. ${ }^{[31]}$ and the light microscope used was an Olympus BX51 (Olympus Optical CO., Tokyo, Japan).

\section{Analysis Of The Reaction Order And Determination Of Kinetic Parameters}

Changes in the vitamin $\mathrm{C}$ content and color parameters were evaluated using the zero and first order kinetic models, equations (3) and (4), respectively, according to Teixeira Neto et al. ${ }^{[32]}$

$C_{t}=C_{0}-k t$

$\ln \frac{c_{t}}{c_{0}}=-k t$

The reaction order was determined with the model that best fitted the experimental data (best determination coefficient $-\mathrm{R}^{2}$ ). The kinetic parameter $\mathrm{k}$ (reaction velocity) was obtained from the best fitted models, and $\mathrm{Q}_{10}$ calculated using this parameter according to equation (5). The half life, $t_{1 / 2}$ life, was calculated using equations (6) and (7) for the zero and first order models, respectively, according to Teixeira Neto et al. ${ }^{[32]}$ :

$Q_{10}=\frac{k T}{k T_{-10}}$ 


\section{ACCEPTED MANUSCRIPT \\ $t_{\frac{1}{2} \text { life }}=\frac{c_{0}}{2 k}$

\section{RESULTS AND DISCUSSION}

\section{Study Of The Effect Of Processing Additives On The Combined OD/HA Process \\ Osmotic Dehydration Parameters}

The values obtained for water loss (WL) and solids incorporation (SI) in the standard trial

(Table 2) were similar to those reported by Jain et al. ${ }^{[19]}$ for the OD of papaya carried out under similar conditions $\left(50^{\circ} \mathrm{C} / 60^{\circ} \mathrm{Brix} / 4 \mathrm{~h}\right)$ : WL of $40 \mathrm{~g} / 100 \mathrm{~g}$; SI of $7.0 \mathrm{~g} / 100 \mathrm{~g}$. On the other hand, the results obtained for WL in the trials with additives (Table 2) were higher than the values obtained in the standard trial $(\mathrm{P})$. The use of citric acid/calcium lactate $(\mathrm{CA} / \mathrm{CL})$ resulted in an increase in WL of approximately $50 \%$. Calcium lactate had a slight greater effect on this parameter than calcium chloride for the same acids. According to Ferrari et al. ${ }^{[31]}$, who studied the use of calcium lactate in the OD of melon, the increase in WL is due to a more open cell structure with the formation of calcium pectates and bridges in the cell wall. However, Table 2 shows that the values for solids incorporation (SI) were slightly lower in the trials with additives as compared to the standard trial, with the exception of the treatment with PME/calcium chloride (PME/CC). Heng et al. ${ }^{[16]}$ observed the same behavior in the OD of papaya with calcium chloride. The authors stated that the association of calcium with the low methoxy pectin in the cell wall causes an increase in the "tortuosity" of the intercellular spaces and also in the local viscosity, decreasing the diffusion of sugar. In agreement with this result, Silva et al. ${ }^{[33]}$, studying the OD of pineapple, reported that the presence of calcium in the solution decreased the diffusivity of sucrose within the samples. Nevertheless, in the trial with 


\section{ACCEPTED MANUSCRIPT}

$\mathrm{PME} /$ calcium chloride $(\mathrm{PME} / \mathrm{CC})$, there was an increase in the value for SI as compared

with the standard treatment $(\mathrm{P})$. The same fact was observed by Van Buggenhout et al. ${ }^{[24]}$ in the OD of strawberry with sucrose and the addition of the same additives, who reported a higher increase in dry matter content (44\%) in the treatment with additives.

The moisture contents of the final products ranged from 14.2 to $18.5 \%$. These differences may be due to small operational variations and to natural variations in the biological tissue. The values for water activity of the resulting products showed significant differences $(\mathrm{p} \leq 0.05)$ and were in the range from 0.60 to 0.65 . However, it was not possible to verify the influence of the different additives on this property.

\section{Texture}

With respect to the texture (cutting force) of the final product, Table 2 shows that, with the exception of $\mathrm{PME} / \mathrm{CC}$, all the treatments resulted in higher values, significantly different from that of the standard treatment $(\mathrm{p} \leq 0.05)$. The highest mean was obtained for the treatment with citric acid/calcium lactate (CA/CL), although this result could also be related to the lower moisture content of the final product for this trial. Ferrari et al. ${ }^{[31]}$ also reported an important increase in the stress of failure of melons pre-treated with calcium lactate, and Rodrigues et al. ${ }^{[17]}$ showed a significant increase in the stress of fracture with the use of calcium chloride in the OD of papaya. On the other hand, the texture of the treatment with PME/calcium chloride (PME/CC) showed no significant difference from the value obtained for the standard treatment $(\mathrm{p}>0.05)$. 


\section{ACCEPTED MANUSCRIPT}

Independent of the results obtained for instrumental texture, all the treatments with additives, including PME/CC, resulted in more integral slices at the end of the OD, which were also easier to handle when compared to the standard treatment. The osmo-dried fruit treated with PME/calcium chloride showed an excellent appearance in terms of volume and form, similar to that reported by Van Buggenhout et al. ${ }^{[24]}$ in the freezing/thawing of strawberries pre-treated with an aqueous solution of PME/calcium chloride.

\section{Instrumental Color}

According to the Table 3, it can be seen that the color parameters of fresh papaya were located in the first quadrant of CIELAB color diagram $\left(a^{*}\right.$ and $\left.b^{*}>0\right)$, corresponding to the region of red and yellow. Besides, a slight predominance of chromaticity parameter $b^{*}$ was observed. According to Sentanin \& Rodriguez-Amaya ${ }^{[6]}$, the main pigments of papaya of Formosa cultivar are lycopene, $\beta$-carotene and $\beta$-cryptoxanthine. For the authors, lycopene, responsible for the red coloration, is the majority pigment, representing $65 \%$ of the total pigments, whereas $\beta$-cryptoxanthine and $\beta$-carotene, responsible for the yellow color, are present as $30 \%$ and $4 \%$, respectively. Due to the variability in the raw material, a dimensionless analysis of the color parameters was carried out (Table 3). A comparison of color of dried products is shown in Figure 1. The processes with additives, with the exception of the treatment with PME/calcium chloride (PME/CC), resulted in lighter product when compared to fresh sample, as indicated by the values for $L^{*}$ dim above 1 (Table 3 ). On the other hand, it is possible to observe that all the processed fruits with additives are lighter than the standard product (Figure 1a). This behavior could be partially explained by the action of the employed organic acids in 


\section{ACCEPTED MANUSCRIPT}

avoiding enzymatic browning. Germer et al.$^{[34]}$ reported similar results in a study with peaches, and related the 'lightening' to a slight crystallization of sugars on the surface. Rodrigues et al. ${ }^{[17]}$ also observed an increase in lightness in their study on the OD of papaya with calcium salts and organic acids, and associated the result to the incorporation of calcium in the vegetable tissue.

With respect to the other color components, Table 3 shows a slight increase in the values for the parameter $b^{*}$ in the process $\left(b^{*}{ }_{\operatorname{dim}}>1\right)$, indicating an intensification of the yellow color, with the exception of the treatments PME/CC and P. However, Figure $1 \mathrm{~b}$ shows that, with the exception of the treatment with PME/calcium chloride (PME/CC), the products obtained with additives are more yellow than that from standard process. This behavior could be explained by the action of the employed organic acids in avoiding enzymatic browning. For parameter $a^{*}$, it was also observed a slight increase during the process $\left(a^{*}{ }_{\text {dim }}>1\right)$, indicating an intensification of the red color for CA/CL, LA/CL and $\mathrm{CA} / \mathrm{CC}$ treatments (Table 3). The redder product obtained by P treatment could be attributed to the differences from the raw material, since the fresh sample showed the highest $a^{*}$ parameter values. In general, in a drying process, the removal of water provides an increase in the color parameters values as a function of the concentration of the pigments from the raw material. However, pigments losses to the syrup during OD may occur, as well as their degradation, resulting in a decrease in the color parameters. ${ }^{[34]}$ Rodrigues et al. ${ }^{[17]}$ reported higher $a^{*}$ and $b^{*}$ values during OD of papaya with additives, and Germer et al. ${ }^{[34]}$ found an increase of yellowness (higher $b^{*}$ values) in the osmotic solution employed during OD of peaches, relating this fact to a leaching of pigments 


\section{ACCEPTED MANUSCRIPT}

from the fruit to the syrup. Similar behavior was pointed out by García-Martínez et al. ${ }^{[35]}$

For the authors, the variations in $b^{*}$ with the reuse of syrup in the OD of kiwi due to leaching of pigments such as $\beta$-carotenes, chlorophylls and xanthophylls from fruit to syrup. Furthermore, according to Heng et al. ${ }^{[16]}$, at the beginning of processing, hydrophobic carotenoids may concentrate in intra cellular spaces during parallel dehydration of papaya (OD process). This leads to a relative increase of their content in the dehydrated fruit. When dehydration time is long enough, the syrup becomes tinted, meaning that a part of the pigments is lost by diffusion.

Based on the results observed, the use of processing additives, in general, helped to preserve the instrumental color of the product, but the combination of PME and calcium chloride was less effective in the maintenance of this quality characteristic.

\section{Vitamin C Content}

The mean vitamin $\mathrm{C}$ content of the raw material used in the trials was $60.12 \mathrm{mg} / 100 \mathrm{~g}$ (Table 4). This value was between those reported by Garcia ${ }^{[36]}$ and by El-Aouar ${ }^{[37]}$ for papaya of Formosa cultivar $(44.30 \mathrm{mg} / 100 \mathrm{~g}$ and $71.31 \mathrm{mg} / 100 \mathrm{~g}$, respectively). The differences are due to variability in the raw material, principally in the state of maturity. The mean loss of vitamin $\mathrm{C}$ during OD for the different treatments was approximately $55 \%$, and the trial performed with PME and calcium chloride (PME/CC) resulted in the greatest retention (Table 4). This result is almost within the range of 30 to $60 \%$ for vitamin $\mathrm{C}$ retention reported by Heng et al. ${ }^{[16]}$ in the OD of papaya under similar process conditions. According to Santos \& $\mathrm{Silva}^{[38]}$, vitamin $\mathrm{C}$ losses occurring during OD are 


\section{ACCEPTED MANUSCRIPT}

related to both chemical deterioration and diffusion of ascorbic acid from the fruit to the solution. Vitamin C content of the dried products was not presented in Table 4, since its determination was compromised, due to the monitoring of the products' weight during hot air drying for the adjustment of the final moisture content, necessary for the other analyses (mainly texture and sensory tests).

In a similar work, An et al. ${ }^{[11]}$ studied the influence of osmotic dehydration (OD) and pulsed vacuum osmotic dehydration (PVOD) with sucrose solutions (50 and $70^{\circ}$ Brix) in combination with air drying on the vitamin $\mathrm{C}$ retention of cherry tomatoes. Air drying led to a great loss of vitamin C, showing a retention rate of only $24.79 \%$. Dried samples pretreated in sucrose solution had higher vitamin C retention rates (about 41-49\%), indicating that osmotic dehydration can greatly help to keep the retention of vitamin C, due to the protective effect of the sugar. The PVOD process had a more favorable effect in keeping vitamin $\mathrm{C}$ retention, due to a greater infusion of sugar solute and shorter hotair drying time. Dried samples pre-treated with $50^{\circ}$ Brix solution under PVOD had the maximum vitamin $\mathrm{C}$ retention of about $55 \%$.

\section{Sensory Analysis}

Concerning the attributes appearance and orange color, the best scores were obtained for the fruits treated with $\mathrm{CA} / \mathrm{CC}$ and $\mathrm{LA} / \mathrm{CC}$, according to Table 5, with no significant difference between them $(\mathrm{p}>0.05)$. This fact can be partially related with the instrumental color results, since these treatments showed similar behavior for the dimensionless variations of $L^{*}$ and $b^{*}$ (Table 3 ). On the other hand, from Figure $1 \mathrm{~b}$, it is also possible to 


\section{ACCEPTED MANUSCRIPT}

see that these treatments resulted in products slightly more yellow. As previously discussed, PME/CC treatment presented lower $L^{*}$ and $b^{*}$ values, but the mean scores for color attribute did not differ from $\mathrm{CA} / \mathrm{CC}$ and $\mathrm{LA} / \mathrm{CC}$ treatments at $\mathrm{p} \leq 0.05$, as seen in Table 5. For the flavor, no significant differences $(\mathrm{p}>0.05)$ were observed between $\mathrm{LA} / \mathrm{CL}, \mathrm{LA} / \mathrm{CC}, \mathrm{CA} / \mathrm{CC}$ and $\mathrm{PME} / \mathrm{CC}$ treatments, but samples produced with $\mathrm{PME} / \mathrm{CC}$ showed the best mean scores, followed by LA/CL and LA/CC treatments. As mentioned before, the highest solids gain (SI) in OD was observed in PME/CC trial (Table 2), which can explain the flavor results in the sensory analysis, as the product of this trial was sweeter. Concerning the texture/elasticity, there was no significant difference $(p>0.05)$ between the means (Table 5), implying that the panelists did not notice the differences pointed out in the previous analysis of instrumental texture (Table 2). With respect to overall quality, PME/CC treatment was the most accepted sample with mean scores around 8.50, showing significant differences $(\mathrm{p} \leq 0.05)$ from $\mathrm{CA} / \mathrm{CL}, \mathrm{LA} / \mathrm{CL}$ and $\mathrm{CA} / \mathrm{CC}$ treatments (Table 5). LA/CC sample also presented high scores for this attribute, not differing significantly from PME/CC treatment ( $\mathrm{p}>0.05)$.

The treatments with lactic acid/calcium chloride (LA/CC) and PME/calcium chloride (PME/CC) were selected for the next step of this work (stability study), based mainly on the results of the sensory evaluation. For this choice, it was taken into account the observation that all the treatments resulted in osmo-dehydrated products with better aspect and greater handling facility as compared to the standard treatment, independent of the instrumental texture results. Despite the lower efficiency in preserving the instrumental color, the treatment PME/CC was chosen for the stability study, mostly due 


\section{ACCEPTED MANUSCRIPT}

to the sensory acceptance scores for flavor and overall quality attributes (Table 5), and also to its innovative character. The choice of the treatment with lactic acid/calcium chloride (LA/CC) was also based in the sensory analyses results (flavor and overall quality attributes), though it showed a greater loss of vitamin $\mathrm{C}$ in comparison to the trial with citric acid (CA/CC), as seen in Table 4 .

\section{Stability Study}

\section{Microscopy}

The images obtained in the light microscopy analysis for fresh papaya and dried papaya (OD/HA) at zero time of the stability study are presented in Figure 2.

Figure 2a shows that the fresh papaya presented turgid, round-shaped cells with a welldefined, consistent cell wall. The presence of pectic substances was evidenced by the toluidine blue (purple color), and they were concentrated in the cell wall and intercellular spaces. Garcia-Noguera et al. ${ }^{[14]}$, working with osmotic dehydration and ultrasound processes prior to convective drying, reported that the cells of fresh strawberry were evenly distributed, showing consistent semicircular shape with few distortion of the cells. Pectin-laced walls were intact and the tissue presented several interlamelar spaces. In the present work, the combined OD/HA process without additives resulted in important alterations in cell format and turgor (Figure 2b). The cell wall was de-structured as evidenced by the loss in adhesion between adjacent walls, intense plasmolysis being observed in the cytoplasm (see arrows). 


\section{ACCEPTED MANUSCRIPT}

According to Figures $2 \mathrm{c}$ and $2 \mathrm{~d}$, OD process carried out with the addition of additives resulted in better maintenance of the cell structure. In the trial with lactic acid/calcium chloride, the cell walls of the samples were thicker due to the formation of calcium pectate (see arrows), which could explain the higher cutting force values observed in the previous part of the work (Table 2). Similar results were reported by Ferrari et al. ${ }^{[31]}$ in melon pre-dried with a sucrose solution containing calcium lactate. However, Pereira et al. ${ }^{[39]}$ found no differences in cell structure between guava pre-dried with calcium lactate and the fresh fruit in a microscopic analysis, even though differences in texture had been found. Figure 2d, which refers to the treatment with PME/calcium chloride, shows less thickening of the cell wall, with an apparent spreading out of the pectic substances throughout the tissue. This fact could explain the lower cutting force obtained for the papaya subjected to treatment with PME/calcium chloride in the previous part of the work (Table 2). Van Buggenhout et al. ${ }^{[19]}$ reported an intense coloration of the cell wall and of the intercellular spaces in the microscopic analysis of osmo-dehydrated strawberry obtained with the addition of PME/calcium chloride during OD with sucrose. However, the authors used larger amounts of enzyme $(0.12 \% \mathrm{v} / \mathrm{v})$ and calcium chloride $(0.5 \% \mathrm{w} / \mathrm{w})$ than employed in the present study. Fraeye et al. ${ }^{[25]}$, studying the infusion of strawberries in a PME/calcium chloride solution, observed that the cell walls were more brightly colored, and related this fact to the formation of a pectin-calcium network. However, OD pre-treatment was followed by high pressure heat treatment, and the results showed that prolonging the heat treatment $\left(70^{\circ} \mathrm{C}\right.$ for more than $\left.10 \mathrm{~min}\right)$ caused a loss of the firmness obtained in the osmotic pre-treatment. Considering this observation, it is possible to say that in the present study the hot air drying performed at $60^{\circ} \mathrm{C}$ could have damaged the 


\section{ACCEPTED MANUSCRIPT}

pectin-calcium network established during the OD step, causing a decrease in texture values (cutting force).

\section{Color Degradation Kinetics}

According to Figure 3, there was a decrease in the parameter $b^{*}$ of the dried papaya with time under the different storage conditions, indicating a loss of yellow color. The zero order kinetic model fitted the experimental data better $\left(\mathrm{R}^{2}\right.$ between 0.83 and 0.92$)$, as seen in Table 6. Koca et al. ${ }^{[40]}$ also reported a decrease in the parameter $b^{*}$ during storage of dehydrated carrot, obtaining zero order kinetic models. In this study, the authors correlated the decay in the chromaticity parameters with degradation of $\beta$-carotene. Table 7 shows that $b^{*}$ values for samples treated with $\mathrm{LA} / \mathrm{CC}$ and stored at $25^{\circ} \mathrm{C}$ were not fitted to kinetic models. No significant difference $(\mathrm{p}>0.05)$ was observed throughout storage, meaning that the yellow color of the product was maintained during the time. Considering this observation and the values obtained for $\mathrm{t}_{1 / 2}$ life at $35^{\circ} \mathrm{C}$ in Table 6 , it can be said that the treatment with LA/CC resulted in greater stability of the yellow color, followed by PME/CC and P treatments. On the other hand, the results for $\mathrm{Q}_{10}$ (Table 6) indicated that the degradation reaction of $b^{*}$ for the samples subjected to PME/CC treatment was less dependent on temperature than that observed for P treatment.

As shown in Figure 4, there was also a decrease in the parameter $a^{*}$ for the different treatments throughout the study, indicating degradation of the red color of dried papaya. The variations in $a^{*}$ followed first order models $\left(\mathrm{R}^{2}\right.$ between 0.80 and 1.0) for $\mathrm{P}$ and LA/CC treatments, with identical equations, as can be seen in Table 6 , resulting in equal 


\section{ACCEPTED MANUSCRIPT}

values for $\mathrm{t}_{1 / 2}$ life at the respective temperatures. The degradation of parameter $a *$ in light guava jam was reported by Moura et al. ${ }^{[41]}$, who also obtained a first order model and $\mathrm{Q}_{10}$ value of 2 for the total color difference $(\Delta \mathrm{E})$. Similar values for $\mathrm{Q}_{10}$ were also reported by Moura et al. ${ }^{[42]}$ for the total color difference $(\Delta \mathrm{E})$ of traditional blackberry jam. The treatment with PME/CC also resulted in first order kinetics for parameter $a^{*}$, with $\mathrm{k}$ values (reaction velocity) much higher than the corresponding values in the other treatments, and lower $\mathrm{t}_{1 / 2}$ life values, indicating less stability of the red color (Table 6). However, the lower value for $\mathrm{Q}_{10}$ obtained for the treatment with $\mathrm{PME} / \mathrm{CC}$, indicated less dependence of the degradation reaction on temperature.

Parameter $L^{*}$ (lightness) remained practically unchanged along storage for samples subjected to treatment with $\mathrm{LA} / \mathrm{CC}$ and stored at $25^{\circ} \mathrm{C}$, indicating that the fruits did not get darker (Table 7). On the other hand, for the other treatments performed at this temperature a slight increase in $L^{*}$ can be seen after 90 days, which means that the papaya pieces became lighter. This could have occurred due to crystallization of sugar on the surface. An increase in $L^{*}$ was also reported by Torreggiani et al. ${ }^{[43]}$ during storage of osmo-dehydrated cherries for 6 months at $25^{\circ} \mathrm{C}$. At $35^{\circ} \mathrm{C}$, no significant variation in the parameter $L^{*}(\mathrm{p}>0.05)$ was observed for the samples treated with PME/CC (Table 7). However, lightness values significantly decreased $(\mathrm{p} \leq 0.05)$ at the end of storage time for $\mathrm{LA} / \mathrm{CC}$ (around $8 \%$ ) and $\mathrm{P}$ (around 21\%) treatments, which is related to a possible browning. 


\section{ACCEPTED MANUSCRIPT}

Based on the above, the addition of lactic acid with calcium chloride to the sucrose syrup used in the OD of papaya presented an effective contribution to color stability of the product during a storage period of 75 to 100 days. This fact may be related to the action of weak acids previously mentioned in avoiding enzymatic browning during process, whose effect is prolonged during storage. The same behavior was not verified for the use of PME with calcium chloride, since the red color component of the dried papaya obtained in this treatment showed an important degradation along the time.

\section{Vitamin C Degradation Kinetics}

The samples (dried fruit) produced for the stability study presented initial vitamin C contents of $152.28 \pm 1.43 \mathrm{mg} / 100 \mathrm{~g}$ (P treatment), $115.59 \pm 0.77 \mathrm{mg} / 100 \mathrm{~g}(\mathrm{LA} / \mathrm{CC}$ treatment) and $144.54 \pm 0.42 \mathrm{mg} / 100 \mathrm{~g}$ (PME/CC treatment), corresponding to retentions of $63 \%, 37 \%$ and $62 \%$, respectively, with respect to the raw material. These contents are relatively high, independently of the observed losses. Thus, the dried papaya obtained by these different processes can be considered an important source of the nutrient.

The first order kinetic model showed good fit $\left(\mathrm{R}^{2}\right.$ from 0.91 to 0.99$)$ for the experimental values of vitamin $\mathrm{C}$ content throughout the stability study at 25 or $35^{\circ} \mathrm{C}$, as can be seen in Table 8 and Figure 5. Similarly, Dermesonlouoglou et al. ${ }^{[44]}$ reported first order kinetic models for the degradation of vitamin C in osmo-dehydrated tomatoes. In another work, Chottamon et al. ${ }^{[12]}$ studied the osmotic treatment (using sucrose, sorbitol and maltose solutions) in combination with air drying of mulberries and also evaluated the influence of different osmotic solutions on drying kinetics, reaction kinetics, and anthocyanins and 


\section{ACCEPTED MANUSCRIPT}

phenolics content. Air drying caused degradation of anthoyanins and phenolics, which followed a zero-order reaction with $\mathrm{R}^{2}$ values ranging from 0.866 to 0.996 . Osmotic treatment with maltose was found to be a good treatment for mulberry drying and preserved the phenolic and anthocyanin contents and provide high antioxidant capacity.

Table 8 shows that the parameters obtained were very close, indicating that the velocity of vitamin C degradation throughout the time was practically the same for the three treatments. This means that the use of lactic acid, calcium chloride or PME/calcium chloride did not contribute to the retention of vitamin $\mathrm{C}$ during storage in comparison to the standard treatment. The half life of the different products at $25^{\circ} \mathrm{C}$ was approximately 60 days (Table 8). Uddin et al. ${ }^{[45]}$ reported a $t_{1 / 2}$ life value of just 5 days for freeze dried guava stored at $30^{\circ} \mathrm{C}$. In a similar work, Roopa et al. ${ }^{[46]}$ showed that the vitamin $\mathrm{C}$ content in dried star fruit, obtained by a combined OD/HA process, did not reduce to half the original value in 10 months of storage at $25^{\circ} \mathrm{C}$. In the present work, the relatively high $\mathrm{Q}_{10}$ values indicated great sensitivity of the vitamin $\mathrm{C}$ degradation reaction in relation to the storage temperature, especially in the treatment with PME/calcium chloride (Table 8). The values for $\mathrm{Q}_{10}$ were within the range reported by Labuza ${ }^{[47]}$ for the degradation of vitamin $\mathrm{C}$ in dehydrated vegetables (from 1.5 to 4 ).

\section{CONCLUSIONS}

The addition of the investigated additives in the osmotic dehydration of papaya resulted in easier handling samples as compared to the standard trial. The instrumental color of the papaya was better preserved during OD/HA process with the additives, despite the 


\section{ACCEPTED MANUSCRIPT}

higher color losses verified in the treatments performed with PME/calcium chloride. Samples treated with PME/calcium chloride and lactic acid/calcium chloride showed higher acceptance scores for overall quality and flavor attributes. With respect to the morphology, the use of the additives resulted in better maintenance of the fruit cellular structure. The combination of lactic acid/ calcium chloride practically kept the yellow color $\left(b^{*}\right)$ of the dried papaya during storage at $25^{\circ} \mathrm{C}$ for 100 days, but the additives did not help to preserve the vitamin $\mathrm{C}$ content along storage. The variations in the color parameters throughout storage were fitted to $1^{\text {st }}$ order kinetic models with $\mathrm{Q}_{10}$ values in the range from 1 to 2 . First order kinetic models were obtained for the degradation of vitamin $C$, with $\mathrm{Q}_{10}$ values ranging from 3 to 4 . In general, papaya pieces treated with lactic acid/calcium chloride presented the best results, especially regarding sensory attributes and color stability throughout storage. The application of PME/calcium chloride was less effective for color stability during storage, but this enzyme contributed to the maintenance of the fruit texture, avoiding an excessive tissue hardening, and also resulted in good sensory acceptance for dried papaya. Therefore, the use of PME deserves to be investigated with others raw materials, calcium salts and processing conditions.

\section{ACKNOWLEDGEMENTS}

The authors are grateful to the National Council for Scientific and Technological Development, CNPq, for the financial support.

\section{NOMENCLATURE}




\section{ACCEPTED MANUSCRIPT}

OD osmotic dehydration

HA hot air drying

OD/HA combined process of osmotic dehydration and hot air drying

PME pectinmethylesterase

$\mathrm{R}^{2} \quad$ coefficient of determination

$\mathrm{Q}_{10} \quad$ temperature coefficient/ quotient

P standard treatment, without aids

$\mathrm{CA} / \mathrm{CL}$ citric acid with calcium lactate

LA/CL lactic acid with calcium lactate

$\mathrm{CA} / \mathrm{CC}$ citric acid with calcium chloride

LA/CC lactic acid with calcium chloride

$\mathrm{PME} / \mathrm{CC}$ pectinmethylesterase with calcium chloride

WL water loss

SI solids incorporation

Ui initial moisture content

Mi initial mass

Uf moisture content at the end of the process

Mf mass at the end of the process

STf total solids content at the end of the process

STi initial solids content

$\mathrm{Ct}$ concentration of the quality component or parameter at time $\mathrm{t}$

Co concentration of the quality component or parameter at zero time

T temperature 


\section{ACCEPTED MANUSCRIPT}

$\begin{array}{ll}\mathrm{k}_{\mathrm{T}} & \text { reaction rate constant at temperature } \mathrm{T} \\ \mathrm{k}_{\mathrm{T}-10} & \text { reaction rate constant at a temperature } 10^{\circ} \mathrm{C} \text { lower } \\ \mathrm{t} & \text { time (day) } \\ \mathrm{t}_{1 / 2 \text { life }} & \text { half life time (day) } \\ L^{*} & \text { lightness ( } L^{*}=0 \text { for black and } L^{*}=100 \text { for white) } \\ a^{*} & \text { chromaticity parameters (green [-] to red }[+]) \\ b^{*} & \text { chromaticity parameters (blue [-] to yellow [+]) } \\ L^{*}{ }_{\text {dim }} & \text { dimensionless parameter } L^{*}\left(L^{*} \text { of dried papaya } / L^{*} \text { of fresh papaya) }\right. \\ a^{*}{ }_{\text {dim }} & \text { dimensionless parameter } a^{*}\left(a^{*} \text { of dried papaya } / a^{*} \text { of fresh papaya) }\right. \\ b^{*}{ }_{\text {dim }} & \text { dimensionless parameter } b^{*}\left(b^{*} \text { of dried papaya } / b^{*} \text { of fresh papaya) }\right.\end{array}$

\section{REFERENCES}

1. Evans, E.; Ballen, F.H. An overview of global papaya production, trade, and consumption. Available in: $<$ http://edis.ifas.ufl.edu/pdffiles/FE/FE91300.pdf $>$. Access in: April $27^{\text {th }}, 2013$.

2. Faostat. Food and Agriculture Organization of the United Nations. Available in: $<$ http://faostat.fao.org/site/342/default.aspx>. Access in: April 27 $7^{\text {th }}, 2013$.

3. El-Aouar, A.A. Study of drying process of Formosa papaya (Carica papaya 1.) fresh and osmotically pretreated. PhD Thesis. College of Food Engineering, State University of Campinas, Campinas, Brazil. (in Portuguese), 2005.

4. NEPA-Center for studies and research on food - Brazilian food composition table. University of Campinas, Campinas, Brazil (in Portuguese), 2011. 


\section{ACCEPTED MANUSCRIPT}

5. Rodriguez-Amaya, D.B.; Kimura, M.; Amaya-Farfan, J. Brazilian sources of carotenoids: Brazilian table carotenoid composition of foods. In: Coradin, L.; Pombo, V.B. (ed.). Ministry of the Environment, Brasília, Brazil. (in Portuguese), 2008.

6. Sentanin, M.A.; Rodriguez-Amaya, D.B. Carotenoid levels in papaya and peach determined by high performance liquid chromatography. Food Science and Technology 2007, 27(1), 13-19.

7. Fiesp/Ital - São Paulo State Federation of Industry/Institute of Food Technology. Brazil Food Trends 2020. Fiesp, São Paulo, Brazil, 2010.

8. Raoult-Wack, A.L. Recent advances in the osmotic dehydration of foods. Trends in Food Science \& Technology 1994, 5(8), 255-260.

9. $\quad$ Fernandes, F.; Rodrigues, S.; Gaspareto, O.C.P.; Oliveira, E. Optimization of osmotic dehydration of papaya followed by air-drying. Food Research International 2006, 39(4), 492-498.

10. Chiralt, A.; Talens, P. Physical and chemical changes induced by osmotic dehydration in plant tissues. Journal of Food Engineering 2005, 67(1), 167-177. 11. An, K.; Li, H.; Zhao, D.; Ding, S.; Tao, H.; Wang, Z. Effect of osmotic dehydration with pulsed vacuum on hot-air drying kinetics and quality attributes of cherry tomatoes. Drying Technology 2013, 31(6), 698-706.

12. Chottamom, P; Kongmanee, R.; Manklang, C; Soponronnarit, S. Effect of osmotic treatment on drying kinetics and antioxidant properties of dried mulberry. Drying Technology 2012, 30(1), 80-87. 


\section{ACCEPTED MANUSCRIPT}

13. Araya-Farias, M.; Macaigne, O.; Ratti, C. On the development of osmotically dehydrated seabuckthorn fruits: pretreatments, osmotic dehydration, postdrying techniques, and nutritional quality. Drying Technology 2014, 32(7), 813-819.

14. Garcia-Noguera, J.; Oliveira, F.I.P.; Gallão, M.I.; Weller, C.L.; Rodrigues, S.; Fernandes, F.A.N. Ultrasound-assisted osmotic dehydration of strawberries: Effect of pretreatment time and ultrasonic frequency. Drying Technology 2010, 28(2), 294-303.

15. Ruiz-López, I.I.; Huerta-Mora, I.R.; Vivar-Vera, M.A.; Martínez-Sánchez, C.E.; Herman-Lara, E. Effect of osmotic dehydration on air-drying characteristics of chayote. Drying Technology 2010, 28(10), 1201-1212.

16. Heng, K.; Guilbert, S.; Cuq, J.L. Osmotic dehydration of papaya: influence of process variable on the product quality. Sciences des Aliments 1994, 10(4), 831-848.

17. Rodrigues, A.; Cunha, R.; Hubinger, M.D. Rheological properties and colour evaluation of papaya during osmotic dehydration processing. Journal of Food Engineering 2003, 59(2-3), 129-135.

18. Pereira, L.M.; Ferrari, C.C.; Mastrantonio, S.D.S.; Rodrigues, A.C.C.; Hubinger, M.D. Kinetic aspects, texture, and color evaluation of some tropical fruits during osmotic dehydration. Drying Technology 2006, 24(4), 475-484.

19. Jain, S.K.; Verma, R.C.; Murdia, L.K.; Jain, H.K.; Sharma, G.P. Optimization of process parameters for osmotic dehydration of papaya cubes. Journal of Food Science and Technology 2011, 48(2), 211-217.

20. Chiumarelli, M.; Ferrari, C.C.; Sarantópoulos, C.I.G.L.; Hubinger, M.D. Fresh cut ‘Tommy Atkins' mango pre-treated with citric acid and coated with cassava (Manihot 


\section{ACCEPTED MANUSCRIPT}

esculenta Crantz) starch or sodium alginate. Innovative Food Science and Emerging Technologies 2011, 12(3), 381-387.

21. Rodrigues, A.C.C.; Pereira, L.M.; Sarantópoulos, C.I.G.L.; Bolini, H.M.A.; Cunha, R.L.; Junqueira, V.C.A.; Hubinger, M.D. Impact of modified atmosphere packaging on the osmodehydrated papata stability. Journal of Food Processing and Preservation 2006, 30(5), 563-581.

22. Torres, J.D.; Castello, M.L.; Escriche, I.; Chiralt, A. Quality characteristics, respiration rates, and microbial stability of osmotically treated mango tissue (Mangifera indica L.) with or without calcium lactate. Food Science and Technology International 2008, 14(4), 355-365.

23. Suttirak, W.; Manurakchinakorn, S. Potential application of ascorbic acid, citric acid and oxalic acid for browning inhibition in fresh-cut fruits and vegetables. Walailak Journal of Science and Technology 2010, 7(1), 5-14.

24. Van Buggenhout, Grauwet, T.; Van Loey, A.; Hendrickx, M. Use of pectinmethylesterase and calcium in osmotic dehydration and osmodehydrofreezing of strawberries. European Food Research and Technology 2008, 22(5), 1145-1154.

25. Fraye, I.; Knockaert, G.; Van Buggenhout, S.; Duvetter, T.; Hendrickx, M.; Van Loey, A.V. Enzyme infusion prior to thermal/high pressure processing of strawberries: mechanistic insight into firmness evolution. Innovative Food Science and Emerging Technologies 2010, 11(1), 23-31.

26. PBMH and PIF Brazilian Program for the Modernization of Integrated Fruit Production and Horticulture. Classification standards of papaya. Available in: $<$ http://www.ceagesp.gov.br/produtor/classific $>$, Access in: May $23^{\text {th }}, 2013$. 


\section{ACCEPTED MANUSCRIPT}

27. Association of Official Analytical Chemists. Official Methods of Analysis of the Association of Official Analytical Chemists, 18th Ed.; AOAC Press: Gaithersburg, MD, 2006.

28. Oliveira, R.G.; Godoy, H.T.; Prado, M.A. Optimization of a colorimetric method to determine ascorbic acids in fruit jelly. Ciência e Tecnologia de Alimentos 2010, 30(1), 244-249. (In Portuguese).

29. Murphy, E.W.; Criner, P.E.; Gray, B.C. Comparisons of methods for calculating retentions of nutrients in cooked foods. Journal of Agricultural and Food Chemistry 1975, 23(6), 1153-1157.

30. Faria, E.V.; Yotsuyanagi, K. Sensory analysis techniques. Institute of Food Technology, Campinas, Brazil. (In Portuguese), 2008.

31. Ferrari, C.C.; Carmello-Guerreiro, S.M.; Bolini, H.M.A., Hubinger, M.D. Structural changes, mechanical properties and sensory preference of osmodehydrated melon pieces with sucrose and calcium lactate solutions. International Journal of Food Properties 2010, 13(1), 112-130.

32. Teixeira Neto, R.O.; Vitali, A.A.; Moura, S.C.S.R. Introduction to kinetics of reactions in food. In: Moura, S.C.S.R.; Germer S.P.M. (ed). Transformation reactions and shelf-life of processed foods. pp. 24-46. Institute of Food Technology, Campinas, Brazil. (in Portuguese), 2010.

33. Silva, K.S.; Fernandes, M.A.; Mauro, M.A. Osmotic dehydration of pineapple with impregnation of sucrose, calcium, and ascorbic acid. Food Bioprocess Technology 2013. Available online. DOI: $10.1007 / \mathrm{s} 11947-013-1049-0$. 


\section{ACCEPTED MANUSCRIPT}

34. Germer, S.P.M. Cultivars, process variables, reuse of sucrose syrup and economic viability of osmotic pre-drying of peaches. $\mathrm{PhD}$ Thesis. College of Agricultural Engineering, State University of Campinas, Campinas, Brazil. (in Portuguese), 2010.

35. García-Martinez, E.; Martinez-Monzo, J.; Camacho, M.M.; Martínez-Navarrete, $\mathrm{N}$. Characterization of reused osmotic solution as ingredient in new product formulation. Food Research International 2002, 35(2-3), 307-313.

36. Garcia, C.C. Evaluation of dehydration of papaya using combined methods. $\mathrm{PhD}$ Thesis. Institute of Biosciences, Language and Physical Sciences (IBILCE), UNESP São Paulo State University, São José do Rio Preto, Brazil. (in Portuguese), 2012.

37. El-Aouar, A.A. Evaluation of the combined process of osmotic dehydration and drying on quality of Taiwan papaya cubes (Carica papaya L.). MS Thesis. College of Food Engineering, State University of Campinas, Campinas, Brazil. (in Portuguese), 2001.

38. Santos, P.H.S.; Silva, M.A. Retention of vitamin C in drying processes of fruits and vegetables - A review. Drying Technology 2008, 26(12), 1421-1437.

39. Pereira, L.M.; Carmello-Guerreiro, S.M.; Hubinger, M.D. Microscopic features, mechanical and thermal properties of osmotically dehydrated guavas. LWT - Food Science and Technology 2009, 42(1), 378-384.

40. Koca, N.; Burdurlu, H.S.; Karadeniz, F. Kinetics of colour changes in dehydrated carrots. Journal of Food Engineering 2007, 78(2), 449-455.

41. Moura, S.C.S.R.; Prati, P.; Vissotto, F.Z.; Ormenese, R.C.S.C.; Rafacho, M.S. Color degradation kinetics in low-calorie strawberry and guava jellies. Ciência e Tecnologia de Alimentos 2011, 31(3), 758-764. 


\section{ACCEPTED MANUSCRIPT}

42. Moura, S.C.S.R.; Rocha Tavares, P.E.; Germer, S.P.M.; Nisida, A.L.A.C.; Alves, A.B.; Kanaan, A.S. Degradation kinetics of anthocyanin of traditional and low-sugar blackberry jam. Food and Bioprocess Technology 2011, 5(6), 2488-2496.

43. Torreggiani, D.; Forni, E.; Rizzola, A. Osmotic dehydration of fruit - part 2: influence of the osmosis time on the stability of processed cherries. Journal of Food Processing \& Preservation 1987, 12(1), 27-44.

44. Dermesonlouoglou, E.K.; Giannakourou, M.C.; Taoukis, P.S. Kinetic modelling of the degradation of quality of osmo-dehydrofrozen tomatoes during storage. Food Chemistry 2007, 103(3), 985-993.

45. Uddin, M.; Hawlader, M.N.; Ding, L.; Mujumdar, A. Degradation of ascorbic acid in dried guava during storage. Journal of Food Engineering 2002, 51(1), 21-26.

46. Roopa, N.; Chauhan, O.P.; Raju, P.S.; Das Gupta, D.K.; Singh, R.K.R.; Bawa, A.S. Process optimization for osmo-dehydrated carambola (Averrhoa carambola L) slices and its storage studies. Journal of Food Science and Technology 2012. Available online. DOI: 10.1007/s13197-012-0756-2.

47. Labuza, T.P. Shelf-life dating of foods. Food \& Nutrition Press, Inc., WestPort, USA, 1982. 


\section{ACCEPTED MANUSCRIPT}

Table 1. Physicochemical properties of fresh papaya.

\begin{tabular}{|l|l|l|}
\hline Analysis & Mean Value & Methods \\
\hline Moisture content & $87.58 \pm 1.43$ & AOAC ${ }^{[2]}$ \\
\hline Titratable acidity $(\mathrm{g}$ citric acid/100 g) & $0.076 \pm 0.001$ & AOAC $^{[27]}$ \\
\hline $\mathrm{pH}$ & $5.49 \pm 0.08$ & Phmeter \\
\hline Total sugar content $(\mathrm{g} / 100 \mathrm{~g})$ & $10.15 \pm 2.04$ & AOAC \\
\hline Reducing sugar content $(\mathrm{g} / 100 \mathrm{~g})$ & $8.94 \pm 1.66$ & AOAC \\
\hline Soluble solids content $\left({ }^{\circ}\right.$ Brix) & $12.00 \pm 0.17$ & Refractometer \\
\hline Vitamin C content $(\mathrm{mg}$ ascorbic acid/100 g) & $53.65 \pm 2.63$ & Oliveira et al. ${ }^{[28]}$ \\
\hline
\end{tabular}

* All data are the mean of triplicate measure \pm standard deviation 


\section{ACCEPTED MANUSCRIPT}

Table 2. Processing additives used, OD/HA parameters and physical properties of the dried papaya subjected to different treatments.

\begin{tabular}{|c|c|c|c|c|c|}
\hline \multirow{2}{*}{ Trial } & \multirow{2}{*}{ Processing additives } & \multirow{2}{*}{ OD parameters (\%) } & \multicolumn{3}{|c|}{ dried product } \\
\hline & & & $\begin{array}{c}\text { Moisture } \\
\text { content } \\
\%\end{array}$ & aw & $\begin{array}{l}\text { Cutting force } \\
\text { (N) }\end{array}$ \\
\hline $\mathrm{CA} / \mathrm{CL}$ & $\begin{array}{l}\text { Citric acid }(0.1 \mathrm{M}) \\
\text { Calcium lactate }(0.5 \mathrm{~g} / 100 \mathrm{~g} \text { syrup) }\end{array}$ & $63.48 \pm 5.08^{\mathrm{c}} 5.07 \pm 0.51^{\mathrm{a}}$ & $14.21 \pm 0.01^{\mathrm{a}}$ & $0.596 \pm 0.001^{\mathrm{a}}$ & $35.98 \pm 3.65^{\circ}$ \\
\hline LA/CL & $\begin{array}{l}\text { Lactic acid }(0.1 \mathrm{M}) \\
\text { Calcium lactate }(0.5 \mathrm{~g} / 100 \mathrm{~g} \text { syrup })\end{array}$ & $61.68 \pm 6.17^{c} \quad 4.47 \pm 0.45^{a}$ & $15.62 \pm 0.16^{b}$ & $0.645 \pm 0.002^{\mathrm{e}}$ & $24.38 \pm 4.67^{b}$ \\
\hline $\mathrm{CA} / \mathrm{CC}$ & $\begin{array}{l}\text { Citric acid } 0.1 \mathrm{M} \\
\text { Calcium chloride }(0.5 \mathrm{~g} / 100 \mathrm{~g} \text { syrup })\end{array}$ & $52.00 \pm 4.16^{c \mathrm{a}} 4.61 \pm 0.37^{\mathrm{a}}$ & $16.97 \pm 0.03^{d}$ & $0.630 \pm 0.002^{c}$ & $28.16 \pm 5.47^{b}$ \\
\hline LA/CC & $\begin{array}{l}\text { lactic acid }(0.1 \mathrm{M}) \\
\text { Calcium chloride }(0,5 \mathrm{~g} / 100 \mathrm{~g} \text { syrup })\end{array}$ & $60.25 \pm 5.42^{\mathrm{c}} 4.29 \pm 0.51^{\mathrm{a}}$ & $18.50 \pm 0.63^{\mathrm{e}}$ & $0.634 \pm 0.001^{d}$ & $24.47 \pm 3.98^{b}$ \\
\hline PME/CC & $\begin{array}{l}\text { PME ( } 1 \mathrm{ml} / \mathrm{kg} \text { fruit) } \\
\text { Calcium chloride ( } 1 \mathrm{~g} / \mathrm{Kg} \text { fruit) }\end{array}$ & $51.37 \pm 5.4^{\mathrm{bc}} \quad 9.94 \pm 1.10^{\mathrm{b}}$ & $16.64 \pm 0.02^{\infty}$ & $0.650 \pm 0.000^{f}$ & $17.64 \pm 5.37^{a}$ \\
\hline $\mathbf{P}$ & Standard - no processing additives & $40.65 \pm 4.3^{\mathrm{ab}} \quad 6.20 \pm 0.93^{\mathrm{a}}$ & $15.78 \pm 0.10^{\text {bc }}$ & $0.624 \pm 0.001^{b}$ & $17.77 \pm 3.43^{\mathrm{a}}$ \\
\hline
\end{tabular}




\section{ACCEPTED MANUSCRIPT}

Table 3. Color parameters of the fresh papaya and the dried papaya subjected to different treatments.

\begin{tabular}{|c|c|c|c|c|c|c|c|c|c|}
\hline \multirow{3}{*}{ Trial } & \multicolumn{9}{|c|}{ color parameters } \\
\hline & \multicolumn{3}{|c|}{ fresh papaya } & \multicolumn{3}{|c|}{ dried papaya } & \multicolumn{3}{|c|}{ dimensionless* } \\
\hline & $\mathrm{L}^{*}$ & $a^{*}$ & $b^{\star}$ & $\mathrm{L}^{*}$ & $a^{*}$ & $b^{*}$ & L*adm & $a^{*} a d m$ & $\mathrm{~b}^{*} \mathrm{adm}$ \\
\hline $\mathrm{CA} / \mathrm{CL}$ & $55.47 \pm 3.46^{\text {क }}$ & $24.58 \pm 1.99^{\circ}$ & $38.17 \pm 2.25^{\mathrm{a}}$ & $59.23 \pm 1.51^{\mathrm{bc}}$ & $24.86 \pm 1.93^{6}$ & $46.44 \pm 1.18^{c}$ & $1.07 \pm 0.07^{\mathrm{a}}$ & $1.01 \pm 0.11^{60}$ & $1.22 \pm 0.08^{6}$ \\
\hline LAVCL & $54.08 \pm 2.97^{b}$ & $25.70 \pm 1.34^{\text {ba }}$ & $40.85 \pm 2.12^{b}$ & $56.39 \pm 2.45^{b}$ & $31.90 \pm 1.45^{d}$ & $45.6 \pm 1.69^{c}$ & $1.04 \pm 0.07^{\mathrm{a}}$ & $1.24 \pm 0.09^{b}$ & $1.12 \pm 0.07^{\mathrm{bc}}$ \\
\hline $\mathrm{CA} / \mathrm{CC}$ & $52.61 \pm 2.98^{\mathrm{ba}}$ & $24.70 \pm 1.97^{\mathrm{a}}$ & $39.92 \pm 2.47^{\mathrm{abc}}$ & $57.69 \pm 3.50^{b c}$ & $28.32 \pm 2.38^{c}$ & $49.16 \pm 3.79^{c}$ & $1.10 \pm 0.09^{a}$ & $1.15 \pm 0.13^{b c}$ & $1.23 \pm 0.12^{b}$ \\
\hline $\mathrm{LA} / \mathrm{CC}$ & $52.40 \pm 1.63^{\text {ba }}$ & $28.03 \pm 1.71^{b}$ & $40.75 \pm 2.13^{\mathrm{abc}}$ & $60.09 \pm 2.80^{c}$ & $24.02 \pm 2.00^{b}$ & $48.55 \pm 3.28^{c}$ & $1.15 \pm 0.06^{\mathrm{a}}$ & $0.86 \pm 0.09^{\mathrm{ac}}$ & $1.19 \pm 0.10^{b}$ \\
\hline $\mathrm{PME} / \mathrm{CC}$ & $58.79 \pm 4.55^{c}$ & $23.91 \pm 3.02^{\mathrm{a}}$ & $39.94 \pm 1.30^{\mathrm{abc}}$ & $56.99 \pm 2.24^{b}$ & $17.26 \pm 2.49^{a}$ & $32.09 \pm 4.74^{\mathrm{a}}$ & $0.97 \pm 0.08^{\mathrm{a}}$ & $0.72 \pm 0.14^{\mathrm{a}}$ & $0.80 \pm 0.12^{\mathrm{a}}$ \\
\hline $\mathrm{P}$ & $49.76 \pm 2.14^{\mathrm{a}}$ & $30.38 \pm 1.79^{c}$ & $40.76 \pm 2.77^{\mathrm{bc}}$ & $48.67 \pm 1.81^{\mathrm{a}}$ & $34.8 \pm 2.20^{e}$ & $36.84 \pm 1.60^{b}$ & $0.98 \pm 0.05^{a}$ & $1.15 \pm 0.10^{\mathrm{bc}}$ & $0.90 \pm 0.07^{\mathrm{ac}}$ \\
\hline \multicolumn{10}{|c|}{${ }^{*}$ parameter $\left(L^{*}, a^{*}, b^{*}\right)_{\text {dim }}=$ parameter of the dried papaya $\left(L^{*}, a^{*}, b^{*}\right) /$ parameter of the fresh papaya $\left(L^{*}, a^{*}, b^{*}\right)$} \\
\hline \multicolumn{10}{|c|}{ Means in the same column with different letters indicate significant differences at $p \leq 0.05$} \\
\hline
\end{tabular}




\section{ACCEPTED MANUSCRIPT}

Table 4. Vitamin C content of the fresh and osmo-dehydrated fruits and the retention values (\%) observed in the different treatments.

\begin{tabular}{|l|l|l|l|}
\hline \multirow{2}{*}{ Trial } & \multicolumn{2}{|l|}{ Vitamin C content (mg/100g) } & Vitamin C retention in OD (\%) \\
\cline { 2 - 3 } & fresh & osmodehydrated & \\
\hline CA/CL & $76.56 \pm 0.26^{\mathrm{f}}$ & $52.84 \pm 2.81^{\mathrm{b}}$ & $33.10 \pm 3.78^{\mathrm{a}}$ \\
\hline LA/CL & $45.47 \pm 0.95^{\mathrm{a}}$ & $41.18 \pm 0.01^{\mathrm{a}}$ & $33.51 \pm 2.09^{\mathrm{a}}$ \\
\hline CA/CC & $64.61 \pm 0.19^{\mathrm{d}}$ & $57.25 \pm 0.44^{\mathrm{c}}$ & $46.62 \pm 0.72^{\mathrm{b}}$ \\
\hline LA/CC & $69.01 \pm 0.15^{\mathrm{e}}$ & $53.36 \pm 0.23^{\mathrm{b}}$ & $34.05 \pm 0.37^{\mathrm{a}}$ \\
\hline PME/CC & $55.18 \pm 0.65^{\mathrm{c}}$ & $59.17 \pm 0.90^{\mathrm{c}}$ & $62.81 \pm 2.06^{\mathrm{d}}$ \\
\hline P & $49.90 \pm 0.57^{\mathrm{b}}$ & $43.23 \pm 0.33^{\mathrm{a}}$ & $56.78 \pm 1.17^{\mathrm{c}}$ \\
\hline
\end{tabular}

* Means in the same column with different letters indicate significant differences at $p \leq 0.05$ 


\section{ACCEPTED MANUSCRIPT}

Table 5. Mean sensory acceptance scores of the dried papaya subjected to different treatments.

\begin{tabular}{|l|l|l|l|l|l|}
\hline & & & Trials & & \\
\hline Attributes & CA/CL & LA/CL & CA/CC & LA/CC & PME/CC \\
\hline appearance & $7.31 \pm 1.82^{\mathrm{b}}$ & $2.62 \pm 1.20^{\mathrm{a}}$ & $9.18 \pm 1.97^{\mathrm{c}}$ & $8.62 \pm$ & $7.75 \pm 2.21^{\mathrm{b}}$ \\
& & & & $1.71^{\mathrm{bc}}$ & \\
\hline orange color & $7.43 \pm 1.90^{\mathrm{b}}$ & $2.68 \pm 1.49^{\mathrm{a}}$ & $9.25 \pm 2.02^{\mathrm{c}}$ & $8.81 \pm$ & $8.37 \pm$ \\
\hline Flavor & $5.68 \pm 2.55^{\mathrm{a}}$ & $6.75 \pm$ & $6.43 \pm$ & $6.62 \pm$ & $7.87 \pm 2.63^{\mathrm{b}}$ \\
\hline texture/elasticit & $7.00 \pm 2.18^{\mathrm{a}}$ & $6.31 \pm 2.73^{\mathrm{a}}$ & $6.18 \pm 2.56^{\mathrm{a}}$ & $6.87 \pm 1.89^{\mathrm{a}}$ & $5.56 \pm 2.99^{\mathrm{a}}$ \\
\hline y & & & & & \\
\hline overall quality & $5.93 \pm$ & $5.43 \pm 2.06^{\mathrm{a}}$ & $7.00 \pm$ & $7.81 \pm$ & $8.50 \pm 2.13^{\mathrm{d}}$ \\
& $1.57^{\mathrm{ab}}$ & & $1.97^{\mathrm{bc}}$ & $1.64^{\mathrm{cd}}$ & \\
\hline
\end{tabular}

* Means in the same line with different letters indicate significant differences at $p \leq 0.05$ 


\section{ACCEPTED MANUSCRIPT}

Table 6. Kinetic parameters for the variations in $a^{*}$ and $b^{*}$ of the dried papaya subjected to different treatments throughout storage.

\begin{tabular}{|c|c|c|c|c|c|c|c|}
\hline Parameter & Treatment & $\begin{array}{c}\text { Reaction } \\
\text { order }\end{array}$ & $\begin{array}{c}\mathbf{T} \\
\left({ }^{\circ} \mathrm{C}\right)\end{array}$ & $\begin{array}{c}\mathbf{k} \\
\left(\text { day }^{-1}\right)\end{array}$ & $\mathrm{R}^{2}$ & $\mathbf{Q}_{10}$ & $\begin{array}{l}\mathbf{t}_{1 / 2} \text { life } \\
\text { (day) }\end{array}$ \\
\hline \multirow[t]{6}{*}{$\mathrm{b}^{\star}$} & $\bar{P}$ & 0 & 25 & $0.113(-)$ & 0.854 & 2.30 & 207.7 \\
\hline & & 0 & 35 & $0.26(-)$ & 0.922 & & 92.6 \\
\hline & $\mathrm{LA} / \mathrm{CC}$ & 0 & 25 & $n f$ & nf & $\mathrm{nf}$ & $\mathrm{nf}$ \\
\hline & & 0 & 35 & $0.13(-)$ & 0.833 & & 212.8 \\
\hline & PME & 0 & 25 & $0.157(-)$ & 0.905 & 1.11 & 142.2 \\
\hline & & 0 & 35 & $0.175(-)$ & 0.865 & & 126.5 \\
\hline \multirow[t]{6}{*}{$a^{*}$} & $P$ & 1 & 25 & $0.002(-)$ & 1,000 & 1.50 & 346.5 \\
\hline & & 1 & 35 & $0.003(-)$ & 0.848 & & 231.0 \\
\hline & $\mathrm{LA} / \mathrm{CC}$ & 1 & 25 & $0.002(-)$ & 0.935 & 1.50 & 346.5 \\
\hline & & 1 & 35 & $0.003(-)$ & 0.803 & & 231.0 \\
\hline & PME & 1 & 25 & $0.008(-)$ & 0.986 & 0.88 & 86.6 \\
\hline & & 1 & 35 & $0.007(-)$ & 0.978 & & 99.0 \\
\hline
\end{tabular}

${ }^{\star} n f=$ not fitted 


\section{ACCEPTED MANUSCRIPT}

Table 7. Color parameters values (not fitted to kinetic models) of the dried papaya subjected to different treatments throughout storage.

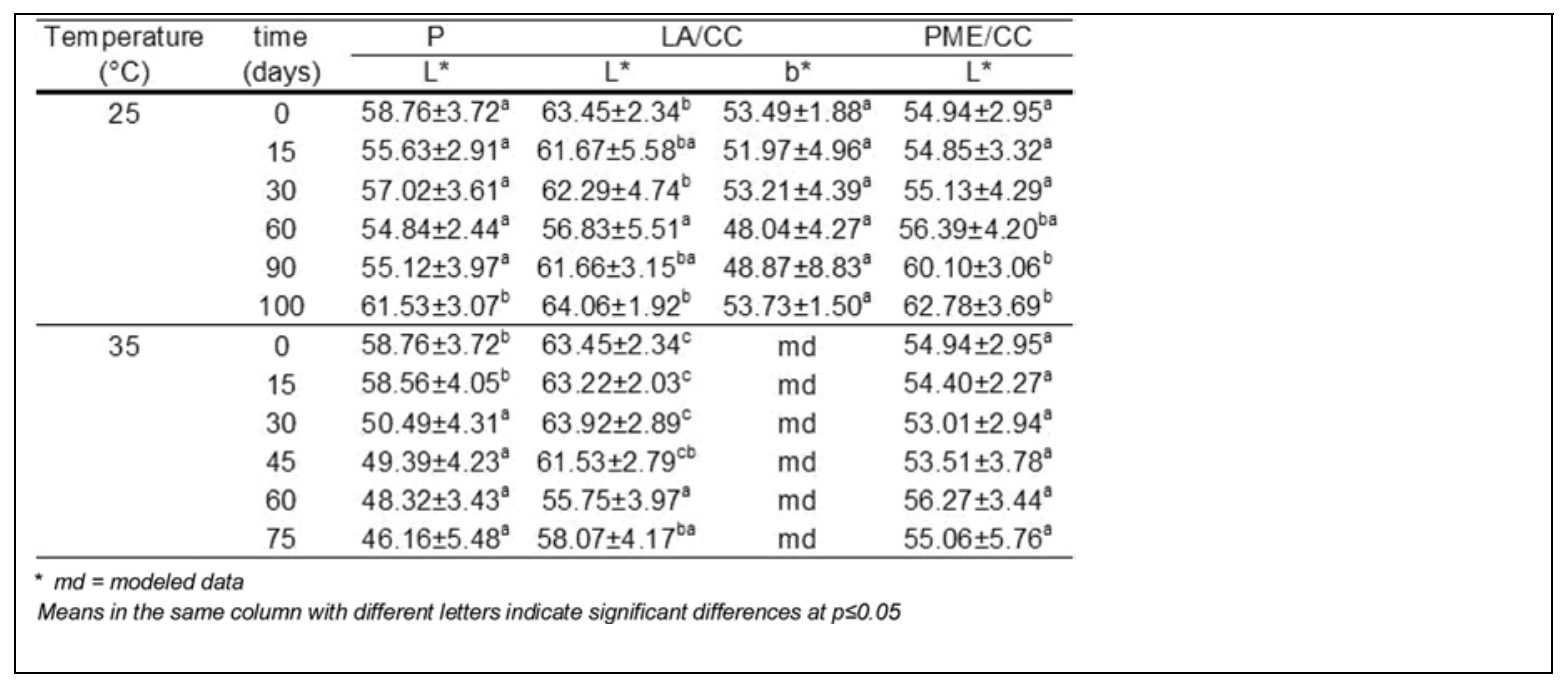




\section{ACCEPTED MANUSCRIPT}

Table 8. Kinetic parameters for vitamin $\mathrm{C}$ degradation of the dried papaya subjected to different treatments throughout storage.

\begin{tabular}{ccccccc}
\hline Treatment & $\begin{array}{c}\text { reaction } \\
\text { order }\end{array}$ & $\begin{array}{c}\mathbf{T} \\
\left({ }^{\circ} \mathbf{C}\right)\end{array}$ & $\begin{array}{c}\mathbf{k} \\
\text { (day }^{-1} \text { ) }\end{array}$ & $\mathbf{R}^{2}$ & $\mathbf{Q}_{10}$ & $\mathbf{t}_{1 / 2 \text { life }}$ \\
\hline $\mathrm{P}$ & 1 & 25 & $0.012(-)$ & 0.982 & 3.08 & 57.8 \\
& 1 & 35 & $0,037(-)$ & 0.991 & & 18.7 \\
\hline $\mathrm{LA} / \mathrm{CC}$ & 1 & 25 & $0.013(-)$ & 0.969 & 3.08 & 53.3 \\
& 1 & 35 & $0.040(-)$ & 0.980 & & 17.3 \\
\hline $\mathrm{PME} / \mathrm{CC}$ & 1 & 25 & $0.010(-)$ & 0.910 & 3.90 & 69.3 \\
& 1 & 35 & $0.039(-)$ & 0.967 & & 17.8 \\
\hline
\end{tabular}




\section{ACCEPTED MANUSCRIPT}

Figure 1. Comparison of color of dried papaya subjected to different treatments: (a) $\mathrm{L}^{*}$ (lightness) and chromaticity parameter $\mathrm{a}^{*}$ (redness); (b) chromaticity parameter $\mathrm{a}^{*}$ (redness) and b* (yellowness): ( ) citric acid/calcium lactate CA/CL; (ø) lactic acid/calcium lactate LA/CL; ( $\mathbf{\Lambda}$ ) citric acid/calcium chloride $\mathrm{CA} / \mathrm{CC}$; (x) lactic acid/calcium chloride LA/CC; $(*)$ pectinmethylesterase/calcium chloride PME/CC; $(\bullet)$ standard (P).

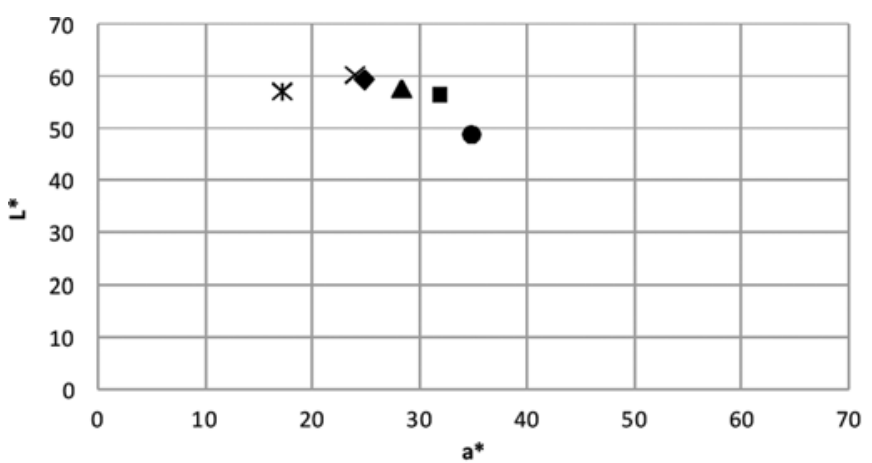

(a)

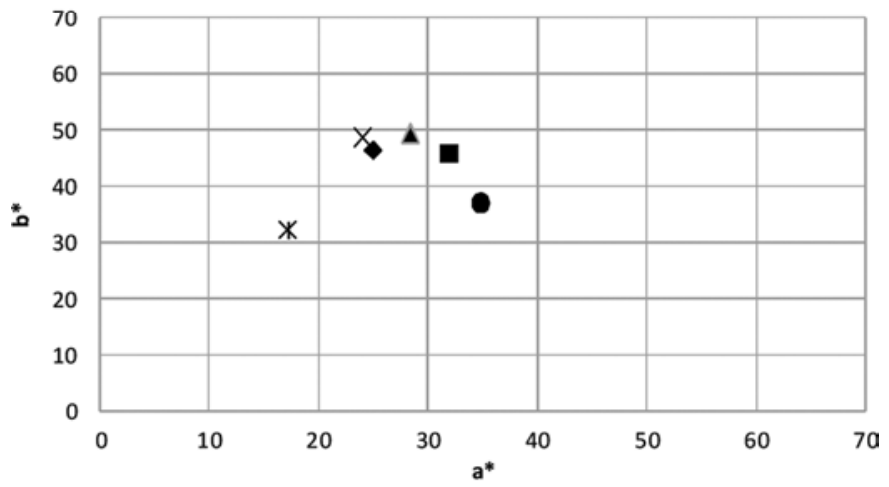

(b) 


\section{ACCEPTED MANUSCRIPT}

Figure 2. Light microscopy images of fresh papaya and dried papaya (OD/HA) at zero

time of the stability study: (a) fresh papaya, (b) OD with no processing additives (P); (c)

OD with lactic acid and calcium chloride (LA/CC); (d) OD with PME and calcium

chloride $(\mathrm{PME} / \mathrm{CC})$. Scale Bar $=200 \mu \mathrm{m}$.

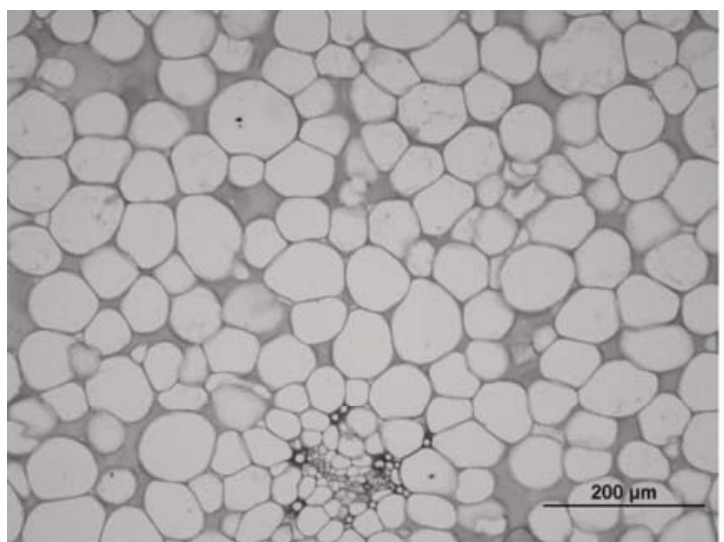

(a)

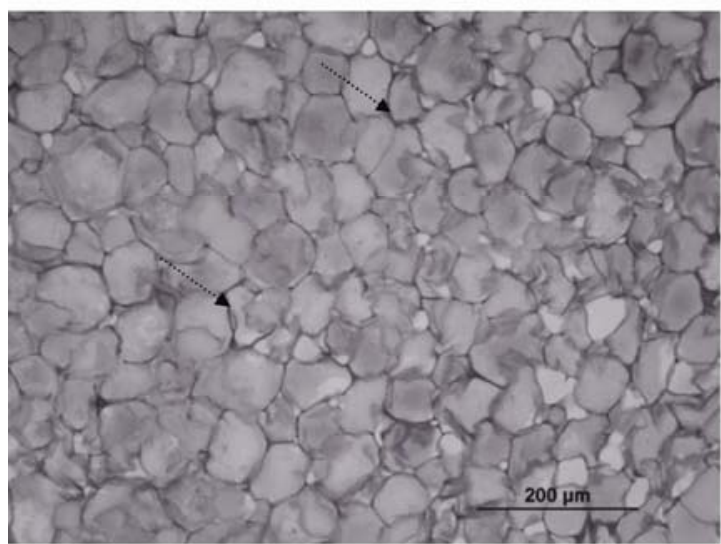

(c)

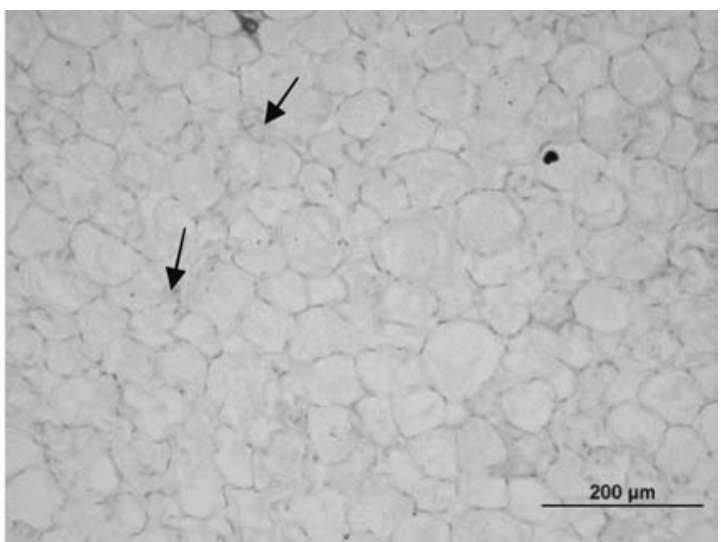

(b)

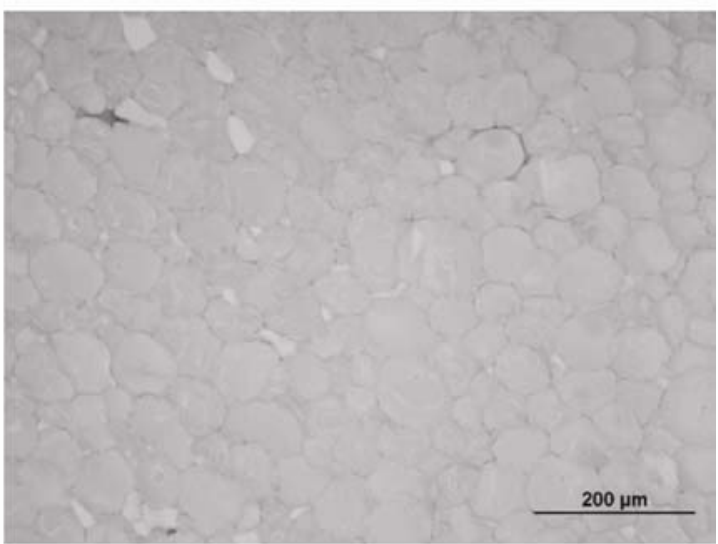

(d) 


\section{ACCEPTED MANUSCRIPT}

Figure 3. Kinetics of the variation in parameter $b^{*}$ (blue-yellow) of the dried papaya subjected to different treatments throughout storage: (a) standard (P); (b) lactic acid/calcium chloride (LA/CC); (c) pectinmethylesterase/calcium chloride (PME/CC).

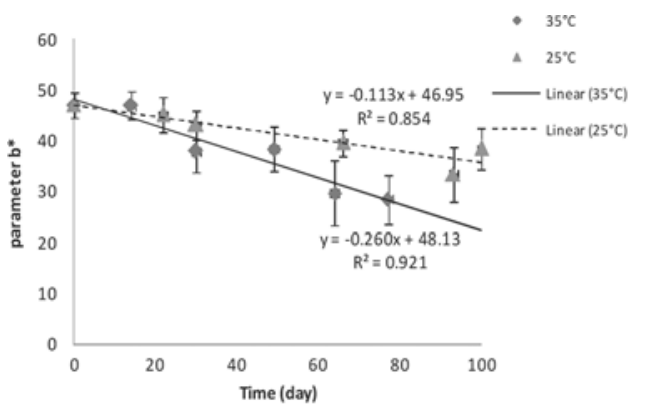

(a)

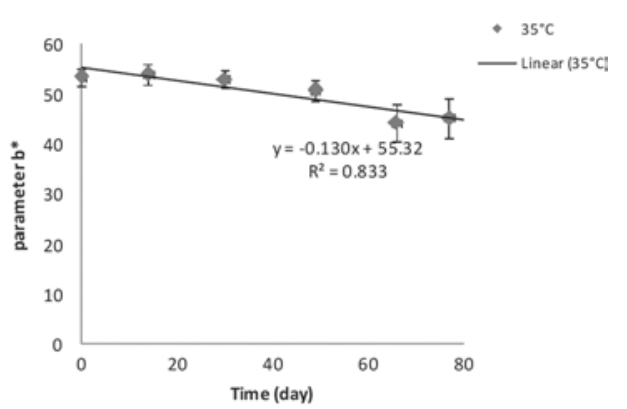

(b)

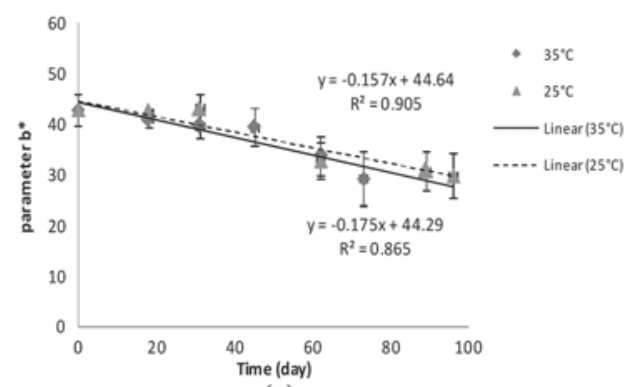

(c) 


\section{ACCEPTED MANUSCRIPT}

Figure 4. Kinetics of the variation in parameter a ${ }^{*}$ (green-red) of the dried papaya subjected to different treatments throughout storage: (a) standard (P); (b) lactic acid/calcium chloride (LA/CC); (c) pectinmethylesterase/calcium chloride (PME/CC).

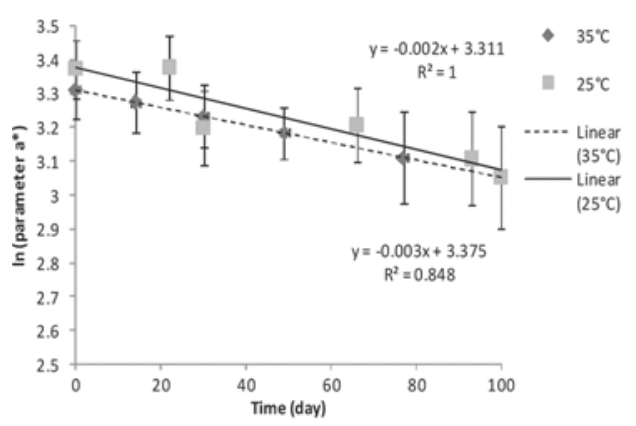

(a)

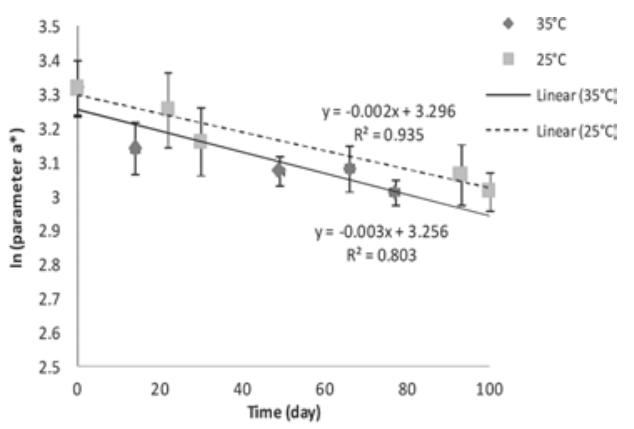

(b)

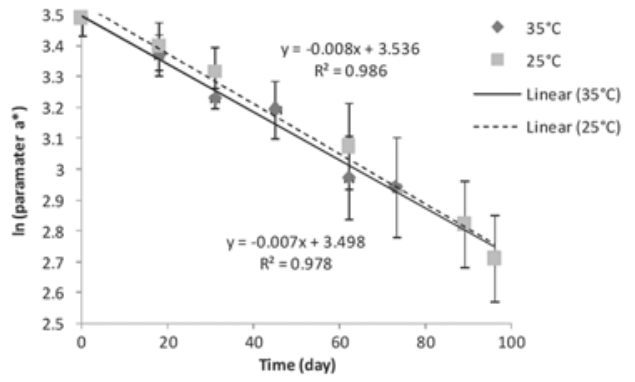

(c) 


\section{ACCEPTED MANUSCRIPT}

Figure 5. Kinetics of vitamin C degradation in dried papaya subjected to different treatments throughout storage: (a) standard (P); (b) lactic acid/calcium chloride (LA/CC); (c) pectinmethylesterase/calcium chloride (PME/CC).

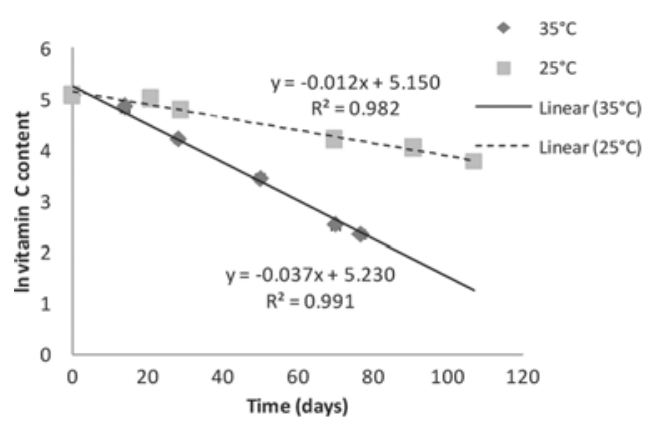

(a)

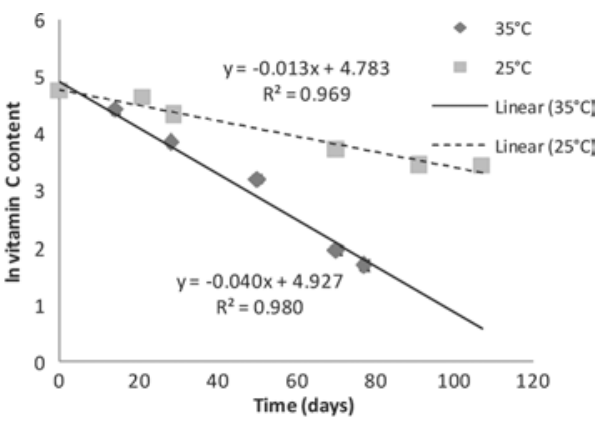

(b)

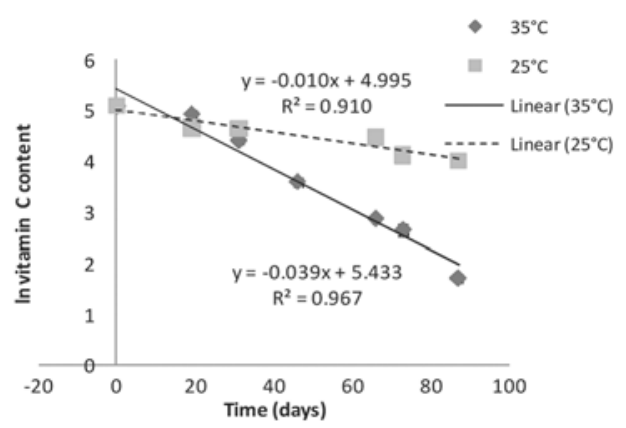

(c) 